\title{
The invention of the Greek prosodic signs
}

\author{
PHILOMEN PROBERT \\ University of Oxford
}

\author{
STEPHANIE ROUSSOU \\ University of Cyprus*
}

\begin{abstract}
Aristophanes of Byzantium is credited with inventing the signs for Greek accents, breathings and vowel lengths, according to a single source: a short text found in two 16th-century Paris manuscripts. The passage has a doubtful history, but the story it tells is of considerable interest. We first provide a new edition of this text, based on a new examination of both manuscripts, and a complete translation. Secondly we argue that the author consulted a source that was in Latin, and that dealt at least in part with the Latin accent. We conclude by considering the implications of our proposal for the text's date and circumstances of composition.
\end{abstract}

\section{Introduction}

Aristophanes of Byzantium is widely believed to have invented the Greek accent marks that we still use today, and possibly some other Greek diacritic marks too. ${ }^{1}$ The only direct evidence that he did so consists of a short text preserved in two 16th-century Paris manuscripts: Parisinus Graecus 2603 (henceforth 'B'), folios $2^{\mathrm{v}}-4^{\mathrm{r}}$, and Parisinus Graecus

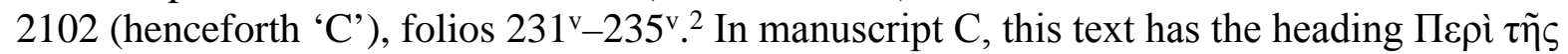

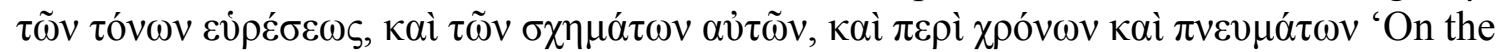
invention of the accents, and their shapes, and on quantities and breathings'; we shall use

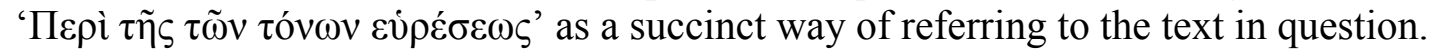

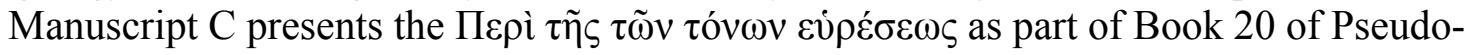

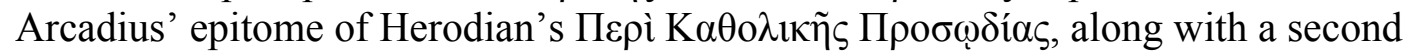

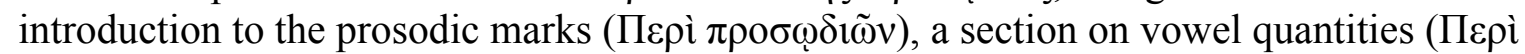

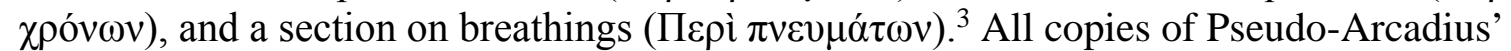
epitome include a Table of Contents, where all except $\mathrm{C}$ include the following entry for Book

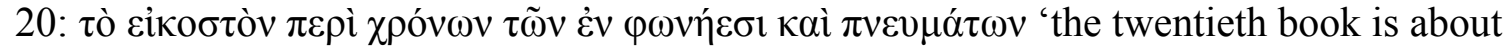
vowel quantities and breathings'. Material purporting to be Book 20 itself, however, appears in manuscript $\mathrm{C}$ and in no other copy of Pseudo-Arcadius' epitome. In manuscript $\mathrm{B}$, the Пвpì $\tau \tilde{\Upsilon} \varsigma \tau \tilde{\omega} v \tau o ́ v \omega v \varepsilon \dot{v} \rho \varepsilon ́ \sigma \varepsilon \omega \varsigma$ appears separately from Pseudo-Arcadius' epitome of Herodian, although this manuscript also contains a text of Pseudo-Arcadius. ${ }^{4}$

The copies of Pseudo-Arcadius in manuscripts B and C both derive ultimately from the copy in Codex Matritensis $4575=32$ ('M'). ${ }^{5}$ In addition, manuscripts B and C are codices

\footnotetext{
* philomen.probert@wolfson.ox.ac.uk; stephanie.roussou@gmail.com. We would like to thank Eleanor Dickey, Nigel Wilson, the participants in the SCS panel on Greek and Latin language and linguistics in 2017 and two anonymous referees for helpful feedback, and the Bibliothèque Nationale de France for enabling Stephanie to examine codices Parisinus Graecus 2102 and Parisinus Graecus 2603 in person. Part of the work presented here arose out of an AHRC Leadership Fellowship held by Philomen in 2015-2017 (grant number AH/M011291/1), and part out of a Humboldt Postdoctoral Research Fellowship held by Stephanie in 2014-2016.

${ }^{1}$ See e.g. Laum (1928) 99-118; Schwyzer (1953) 374; Pfeiffer (1968) 180-81; Callanan (1987) 30-31; cautiously Prauscello (2006) 33-38 and Probert (2006) 21-22. Compare also Nagy (2000) 15-16, who argues that Aristophanes of Byzantium played a role in systematising a pre-existing system for marking accents.

${ }^{2}$ We adopt the sigla 'B' and 'C' used by M. Schmidt (1860) in his text of Pseudo-Arcadius, although Schmidt

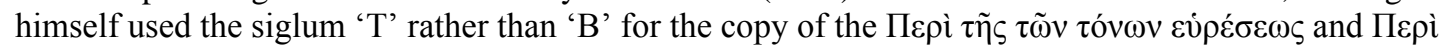
$\pi \rho 0 \sigma \omega \delta i \tilde{\omega} v$ sections found in Parisinus Graecus 2603, to reflect this manuscript's inclusion of these sections among texts attributed to Theodosius, and separately from the text of Pseudo-Arcadius. For a partial transcription of the text in both manuscripts, see Lameere (1960) 90-92. For digital images of the relevant part of B, see $<$ https://gallica.bnf.fr/ark:/12148/btv1b10723382k/f10>; and for the relevant part of C, see $<$ https://gallica.bnf.fr/ark:/12148/btv1b10723675n/f236>.

${ }^{3}$ See Roussou (2018) 52-57.

${ }^{4}$ See Nauck (1848) 12 n. 2; Lentz (1867) xxxviii; Laum (1928) 99; Roussou (2018) 53.

${ }^{5}$ See Roussou (2018) 83-100.
} 
gemelli, that is to say they share an immediate common source, as far as their texts of PseudoArcadius are concerned. ${ }^{6}$ Since only the copy of Pseudo-Arcadius in C includes a Book 20, it follows that either (i) the common source of B and C included a Book 20 in its text of PseudoArcadius, and this was copied by $\mathrm{C}$ but omitted by $\mathrm{B}$, or (ii) the common source did not include a Book 20 and this material was added by the scribe of $\mathrm{C}$. The second possibility is by far the more likely, since manuscript B contains a marginal note at the end of Book 19 stating that Book 20 is missing. The scribe of $\mathrm{C}$ (folios $88^{\mathrm{r}}-244^{\mathrm{r}}$ ) was a known forger of his time, Jacob Diassorinus $;{ }^{7}$ it is clear that he put the material purporting to be Book 20 together from a series of other sources, ${ }^{8}$ to repair the loss of the original Book 20. It follows that the sections that comprise Book 20 in manuscript $C$ were not originally part of Pseudo-Arcadius' epitome of Herodian; for this reason Roussou excludes them from her edition of Pseudo-Arcadius (Roussou 2018). ${ }^{9}$

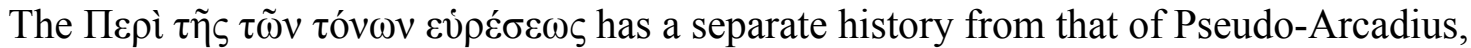
then, but this does not tell us where the material originated in the first place. Indeed, the point

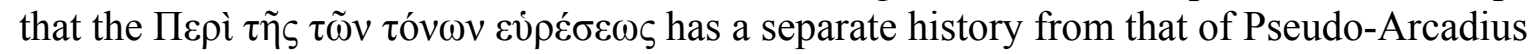
makes it worth asking when, where and by whom this text was written.

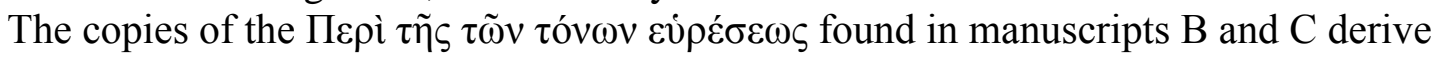
independently from a common source, ${ }^{10}$ in all likelihood the manuscript from which both manuscripts derive their copies of Pseudo-Arcadius. In the following section, we provide a

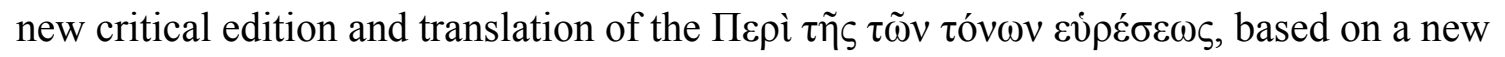
examination of both manuscripts. Aspects of our text and translation will be defended in section 3, where we make a new proposal on the text's prehistory.

\section{Critical edition and translation ${ }^{11}$}

\footnotetext{
${ }^{6}$ For the point that this common source derives its copy of Pseudo-Arcadius from codex Matritensis 4575 ('M'), as first argued by Schneider (1887) 41-42, see now Roussou (2018) 95-98.

${ }^{7}$ For the point that Diassorinus copied folios $88^{\mathrm{r}}-244^{\mathrm{r}}$, but not the earlier part of the manuscript, see García Bueno (2017) 125, 184, 316. On Diassorinus' role as a forger, see Cohn (1888) 141-43; Galland (1882) 17; García Bueno (2017) 11.

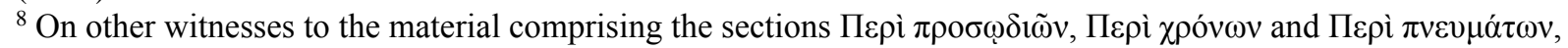
see Roussou (2018) 53-54, 55-57.

${ }^{9}$ See Roussou (2018) 52-57.

${ }^{10}$ The text in B is clearly not derived from the one in C, not least because where manuscript B has the good

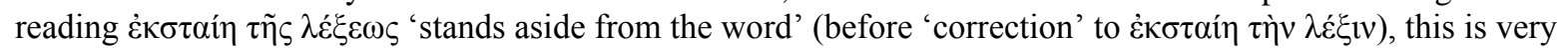

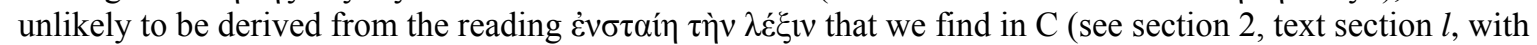
discussion in sections 3.2 and 3.3.4). The text in $\mathrm{C}$ is also not derived from the one in $\mathrm{B}$. This point can be

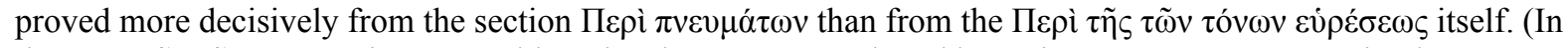

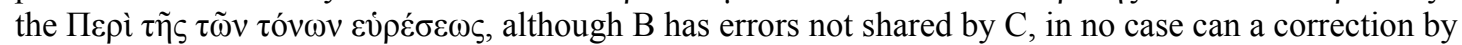
Diassorinus be completely ruled out.) For example, the material printed by M. Schmidt (1860) at p. 225, line 26p. 226, line 13 appears in manuscript $\mathrm{C}$ but not in B. This material therefore cannot be derived from manuscript B, but it was also not composed from scratch by Diassorinus: related material appears in the Lexicon de spiritibus (214. 14-19 and 213. 34-214. 8 Valckenaer $^{2}=240.27-241.2$ and 240.11-21 Valckenaer $^{1}$ ), with manuscript evidence predating Diassorinus (e.g. the fifteenth-century manuscript Par. Gr. 1270, at f. 244r, line

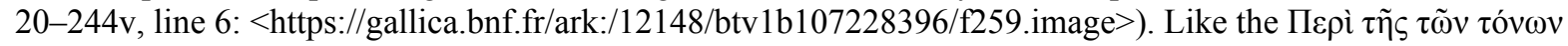

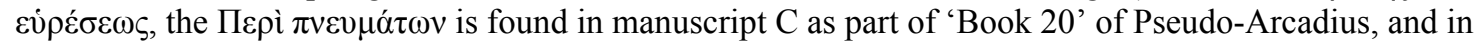
manuscript B among material attributed to Theodosius (see Roussou (2018) 53-54). Both sections (and others found in both places) are likely to have found their way into these two manuscripts by a similar route, so that if

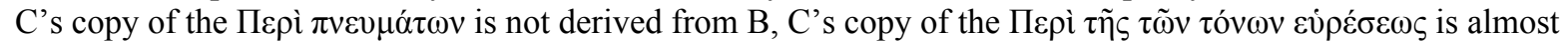
certainly not derived from B either.

${ }^{11}$ The punctuation given in this edition is editorial, and we do not record variants pertaining only to accents, breathings, or iota subscripts, except where these are significant for the sense. Prauscello (2006) 34-35, 37 also offers translations for two portions of the text-the first comprising our section a and most of $b$, and the second comprising most of our section $\mathrm{f}$.
} 


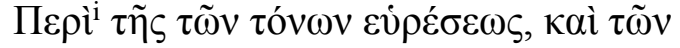

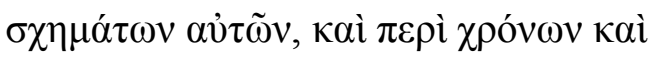

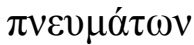

Signs for the accents, quantities and breathings, and their names:

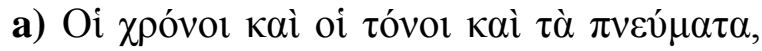

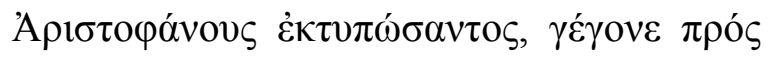

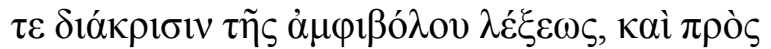

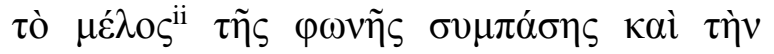

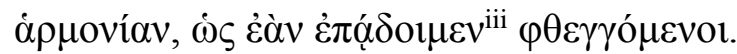

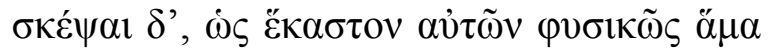

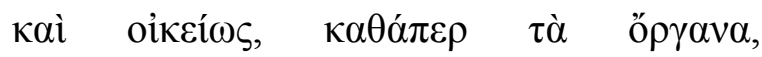

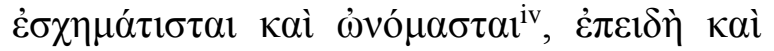

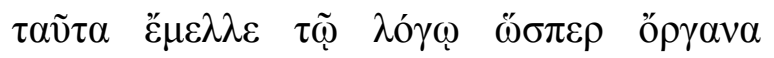
है $\sigma \varepsilon \sigma \theta \alpha$.

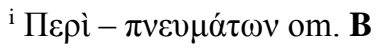

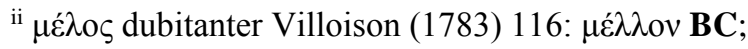
$\mu \varepsilon \lambda \omega \delta$ «òv Jacobi apud Lentz (1867) xxxviii

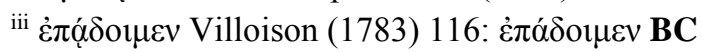

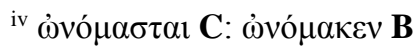

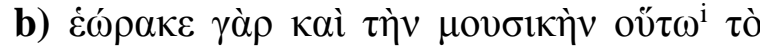

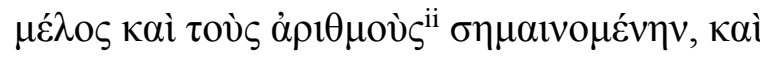

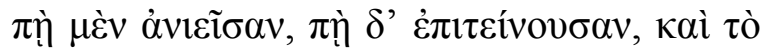

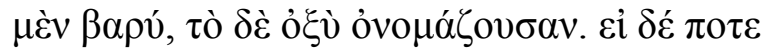

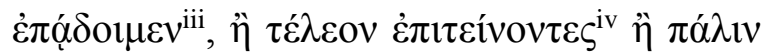

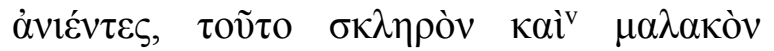

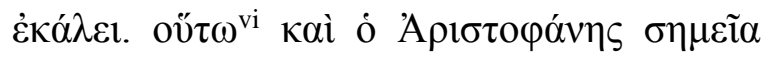

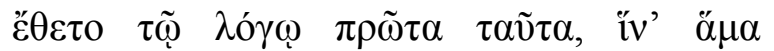

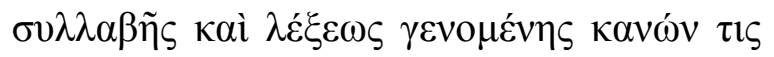

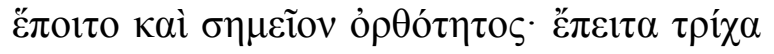

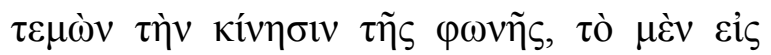

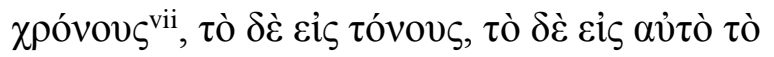

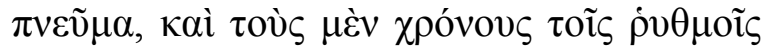

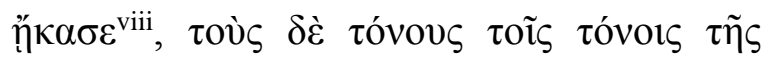

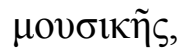

${ }^{\mathrm{i}}$ ov๊ $\tau \omega \mathbf{C}$ : ov๊ $\tau \omega \varsigma \mathbf{B}$

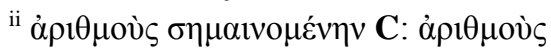

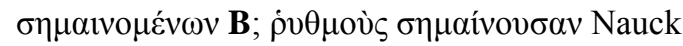
(1848) 14

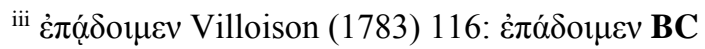

On the invention of the accents, and their shapes, and on quantities and breathings

a) The (signs for) quantities, accents and breathings, which Aristophanes (of Byzantium) created, were devised for the purposes of disambiguating an ambiguous word, and for the singing of the whole voice and the melody, as if we were to sing along to our speaking. Now consider how each of them has naturally and suitably been shaped and named, like musical instruments, since these were in fact to be like musical instruments for speech.

b) For he saw that music too indicates the melody and the rhythms like this, and that it slackens here and tightens there, and that it calls the first of these 'grave' and the second 'acute'. And if ever we sang by either tightening (the voice) completely or relaxing it again, it ${ }^{12}$ called this harsh and soft. In this way Aristophanes too first established these signs for speech, so that whenever there is a syllable or word a rule and sign of correctness would follow. Then dividing the movement of the voice in three ways-into lengths, pitches and the breath itself - he both likened the lengths to the rhythms and the pitches to the pitches of music,

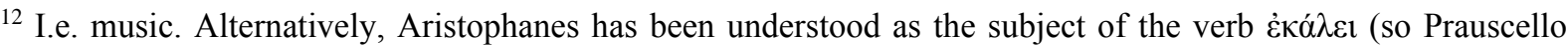

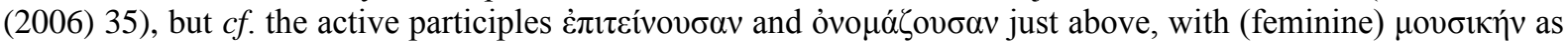
subject. 


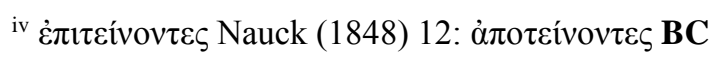

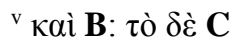

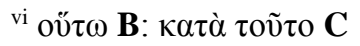

vii $\chi \rho o ́ v o v \varsigma \mathbf{B}^{\text {p.c. }} \mathbf{C}$ : $\tau$ óvovৎ $\mathbf{B}^{\text {a.c. }}$

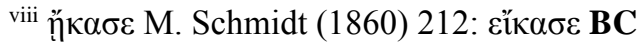

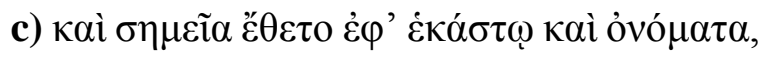

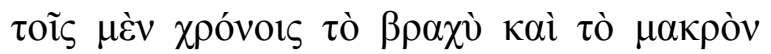

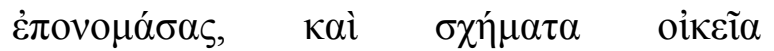

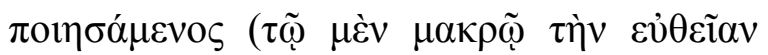

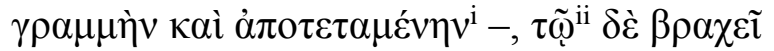

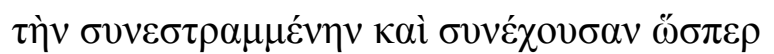

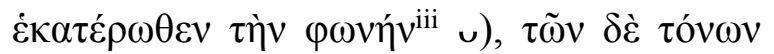

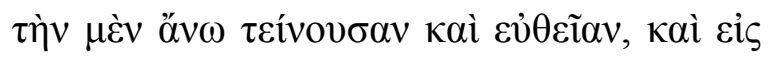

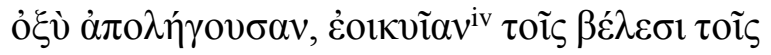

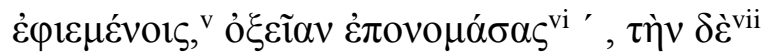

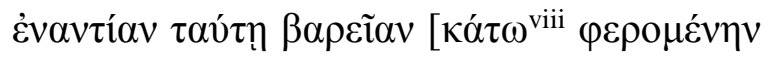

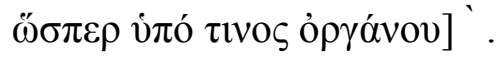

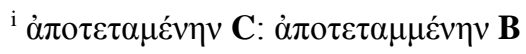

ii $\tau \tilde{\omega} \ldots \beta \rho \alpha \chi \varepsilon \tilde{\imath} \mathbf{C}: \tau \tilde{\omega} \ldots \beta \rho \alpha \chi \nu ̀ ~ B$

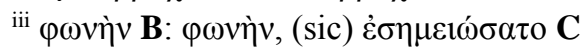

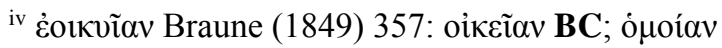
dubitanter Nauck (1848) 15

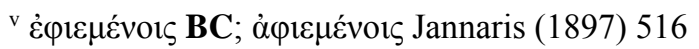

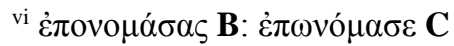

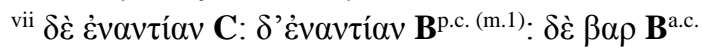

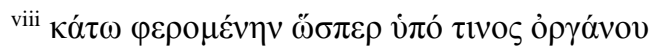

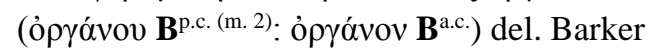
(1820) 187: om. C
}

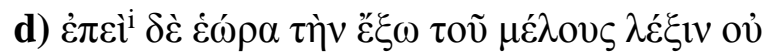

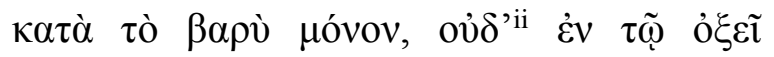

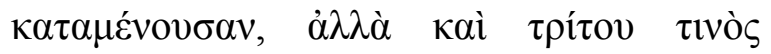

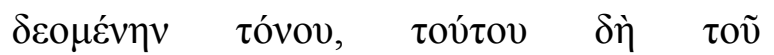

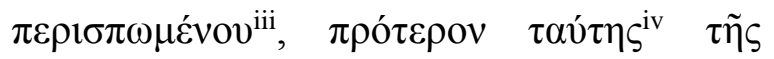

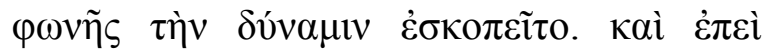

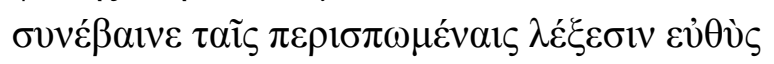

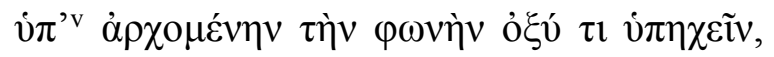

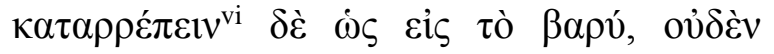

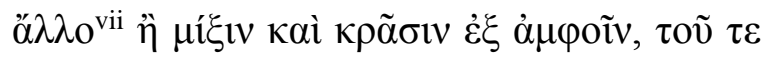

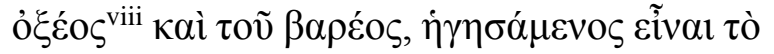

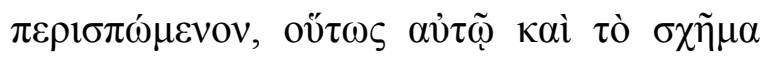

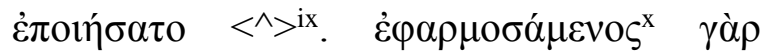

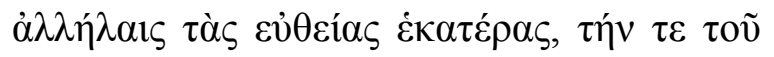

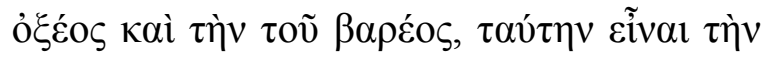

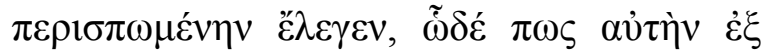

c) and he established signs and names for each one, applying 'short' and 'long' as names for the lengths, and making suitable shapes (for the long the straight and extended line -, for the short the one that is curled up and (as it were) holds the voice in from each side $v$ ), and among the accents, calling the (line?) that tends upwards and is straight, and ends in a point, and resembles launched missiles, 'acute' ', and the opposite of this one [carried downwards as if by some instrument] 'grave' .

d) And since he saw that speech independent of song does not just stay on the low pitch, nor on the high pitch, but needs a third pitch as well, namely the circumflex, he first considered the force of this sound. And since it turned out that for perispomenon words something sounds high right at the beginning of the (vowel) sound, and then inclines downwards as towards the low pitch, considering the circumflex to be nothing other than a mixture and mingling of both accents, the acute and the grave, this is also how he made its shape: ^. For after fitting together the two straight lines, the one of the acute accent and the one of the grave, he said this was the circumflex, thus calling it 


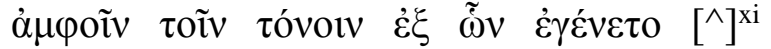

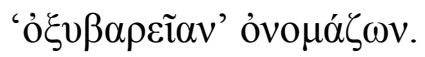

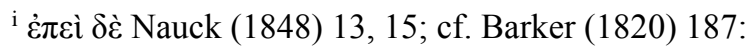
$\dot{\varepsilon} \pi \varepsilon 1 \delta \grave{~ B C}$

ii ov̉ ' '่̇ $\tau \tilde{\omega}$ ỏ $\xi \varepsilon \tilde{~ N a u c k ~(1848) ~ 13, ~ 15 ; ~ c f . ~ B a r k e r ~}$

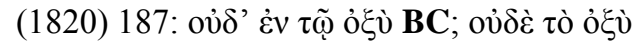
Jannaris (1897) 516

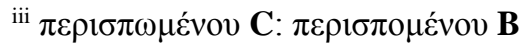

iv $\tau \alpha u ́ \tau \eta \varsigma$ scripsimus: $\dot{\varepsilon} \alpha v \tau \tilde{\eta} \varsigma$ BC; $\alpha u ̉ \tau \tilde{\eta} \varsigma$ Nauck (1848) 13, 15

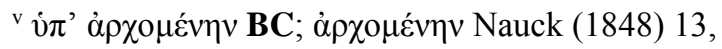
15, sed cf. Braune (1849) 357; $\alpha$ $\pi \alpha \rho \chi \mu \varepsilon \dot{v} \eta \nu$ Jannaris (1897) 516

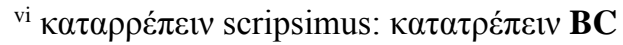

vii $\alpha \hat{\lambda} \lambda$ o Nauck (1848) 13, 15: $\dot{\alpha} \lambda \lambda^{\prime}$ BC

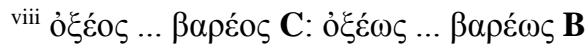

ix $\wedge$ addidimus

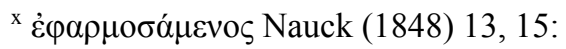

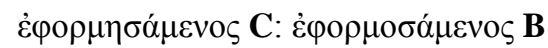

xi $\wedge$ delevimus: ${ }^{\wedge} \mathbf{C}: \sim \mathbf{B}$

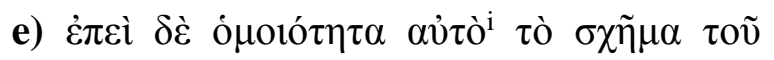

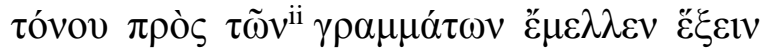

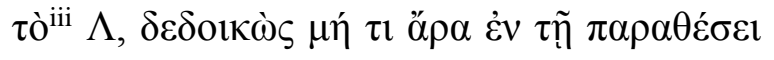

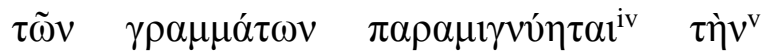

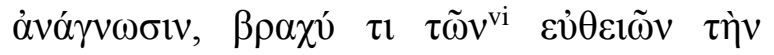

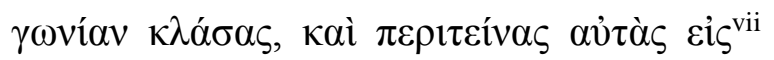

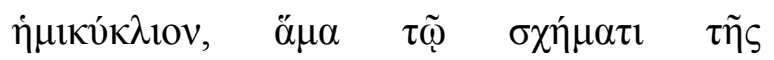

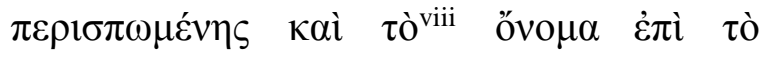

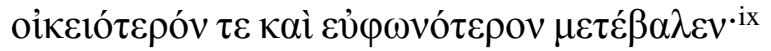

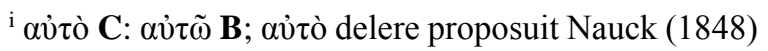

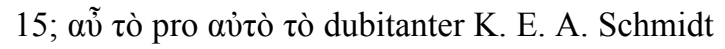
(1859) 596

ii $\check{E} v$ ante $\tau \tilde{\omega} v \gamma \rho \alpha \mu \mu \alpha ́ \tau \omega v$ excidisse suspicatus est

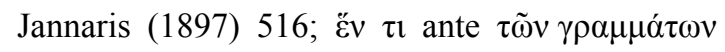
excidisse suspicatus est K. E. A. Schmidt (1859) 596

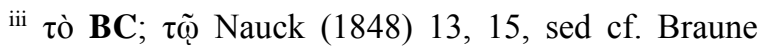
(1849) 357, K. E. A. Schmidt (1859) 596, et Lentz (1867) xxxix

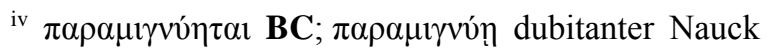
(1848) 15

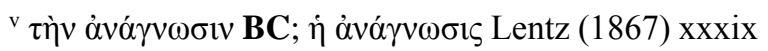

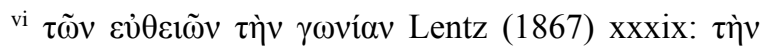

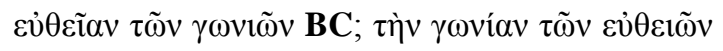
Braune (1849) 357

vii $\varepsilon i \varsigma \zeta$ dubitanter Nauck (1848) 15: हैv BC

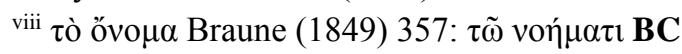

oxubareia from the two accents it was made out of.

e) And since this shape for the accent was likely to bear a similarity to $\Lambda$ among the letters, fearing lest anything in the placing of letters side by side should mix up the reading, by bending the corner of the sides a little and stretching them round into a semi-circle, along with the shape of the circumflex he also changed its name to a more suitable and better-sounding one. 


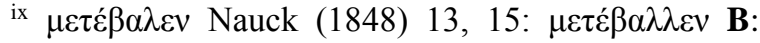
$\mu \varepsilon \tau \dot{\varepsilon} \beta \alpha \lambda \lambda \varepsilon v^{*} \cdot \mathbf{C}$

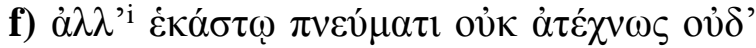

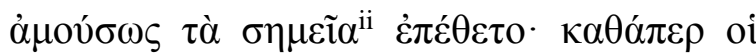

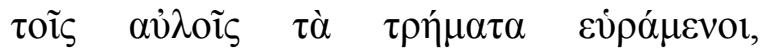

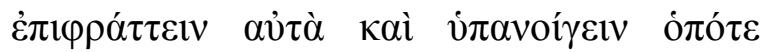

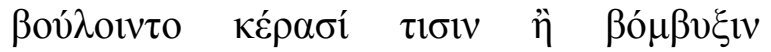

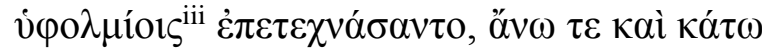

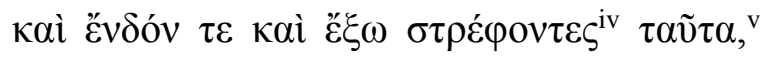

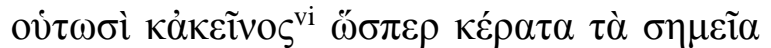

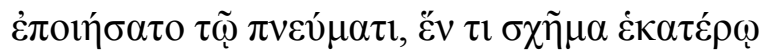

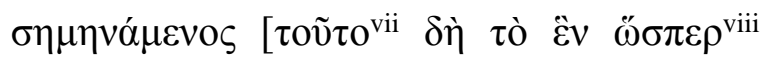

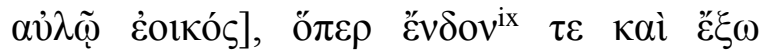

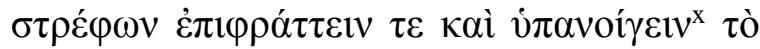

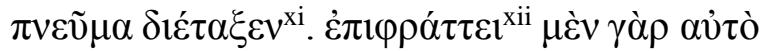

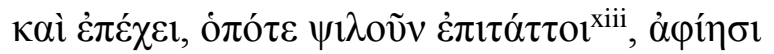

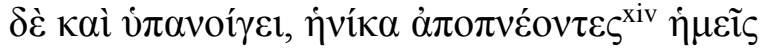
$\delta \alpha \sigma \varepsilon ́ \omega \varsigma \lambda \varepsilon^{\gamma} \gamma \varepsilon v \dot{\alpha} v \alpha \gamma \kappa \alpha \zeta o ́ \mu \varepsilon \theta \alpha$.

i $\dot{\alpha} \lambda \lambda$ ’ $\dot{\varepsilon} \kappa \alpha ́ \sigma \tau \omega$ BC; aut $\alpha \lambda \lambda \grave{\alpha} \kappa \alpha i ̀ ~ \varepsilon ́ \kappa \alpha ́ \sigma \tau \omega$ legendum esse aut verba nonnulla post $\mu \varepsilon \tau \varepsilon \dot{\beta} \beta \alpha \varepsilon \varepsilon v$ excidisse suspicatus est M. Schmidt (1860) 213

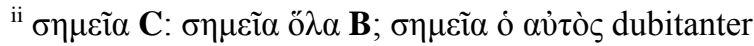
Nauck (1848) 15

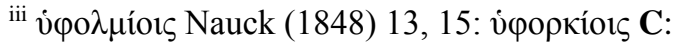

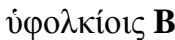

${ }^{\text {iv }} \sigma \tau \rho \varepsilon ́ \varphi o v \tau \varepsilon \varsigma \mathbf{C}: \sigma \tau \rho \varepsilon ́ \varphi o v \tau \alpha \varsigma \mathbf{B}$

${ }^{\mathrm{v}} \tau \alpha \tilde{\tau} \tau \alpha$ BC: $\alpha$ $\tau \alpha ́$ proposuit Nauck (1848) 15

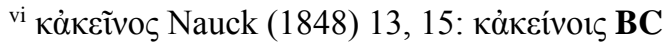

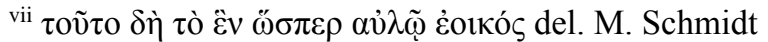

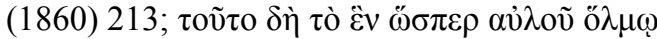
\&̇oukós Lentz (1867) xxxix

viii Schmidt (1860) 213 in apparatu critico

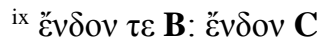

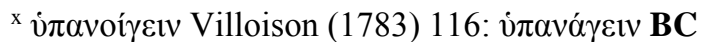

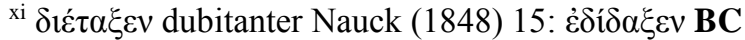

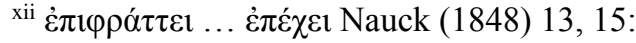

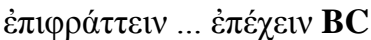

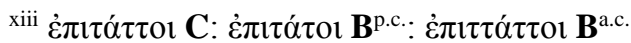

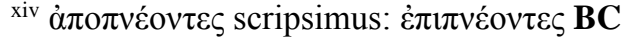

\section{Signs for $\boldsymbol{\pi \alpha} \theta \boldsymbol{\eta}$ and for punctuation:}

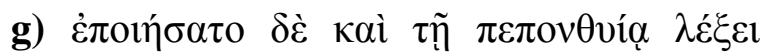

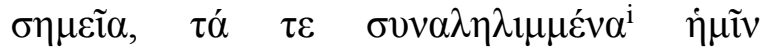

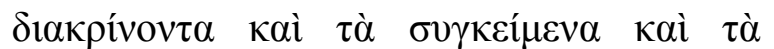

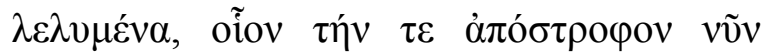

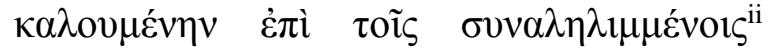

f) And he not unskilfully or unartfully assigned signs to each breathing. Just as those who invented the holes for auloi contrived to obstruct and open them whenever they wanted with some kerata or bombükes hypholmioi, by turning these up and down and inwards and outwards, in this way Aristophanes too made the signs for the breath like kerata, providing a single shape for each [this one as if resembling an aulos], and by turning this inwards and outwards he set it up to obstruct and open the breath. For it obstructs and checks the breath whenever it commands us to pronounce an unaspirated sound, but it lets it out and opens its tap whenever we are made to breathe hard and speak with aspiration. g) And he made signs for a word that has undergone a modification, and these distinguish for us elided words, and compounded and separate ones, for example setting up what is now called the apostrophe 


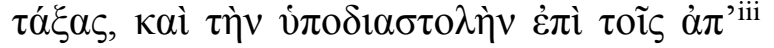

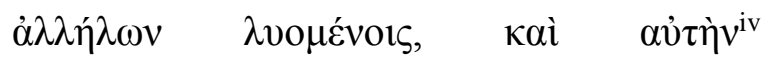

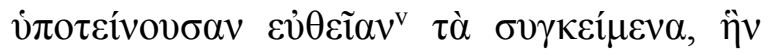

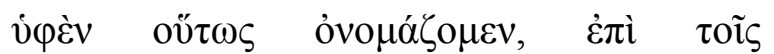

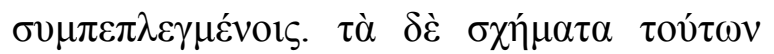

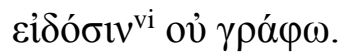

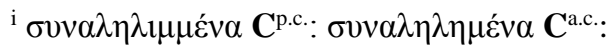
$\sigma v v \alpha \lambda \lambda \eta \lambda \eta \mu \varepsilon \dot{\varepsilon} \alpha \mathbf{B}$

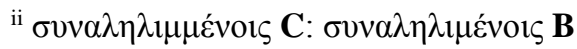

iii $\dot{\alpha} \pi$ ' Nauck (1848) 14: '̇ं $\pi$ BC

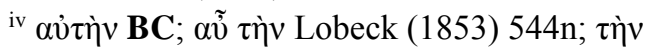
dubitanter Nauck (1848) 15

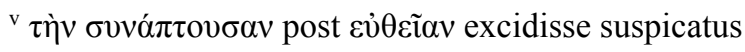
est Lobeck (1853) 544n

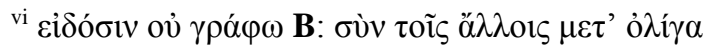

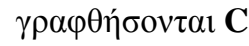

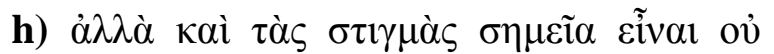

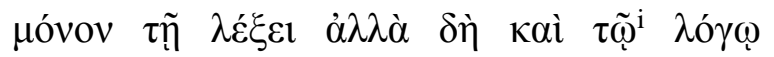

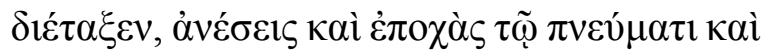

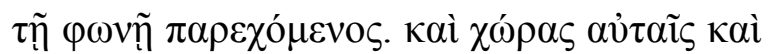

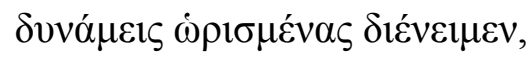

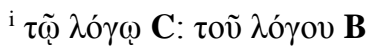

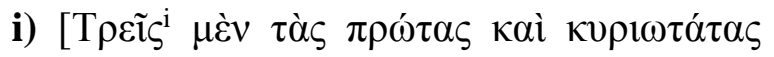

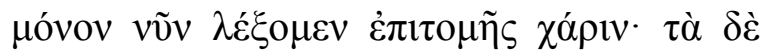

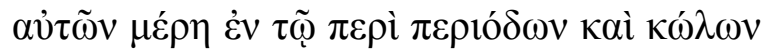

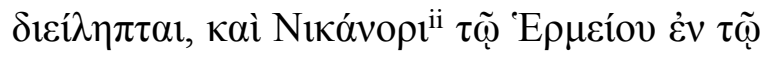

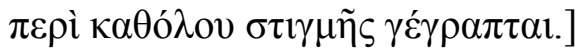

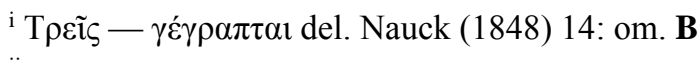

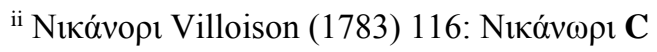

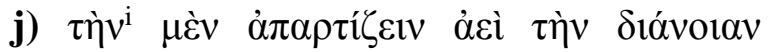

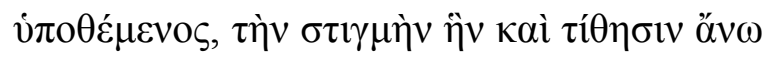

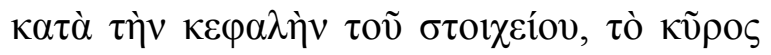

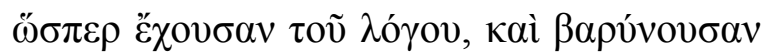

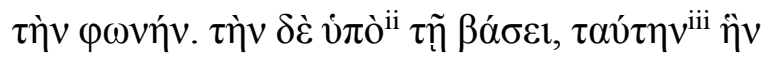

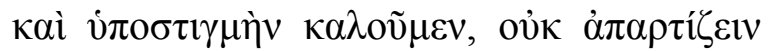

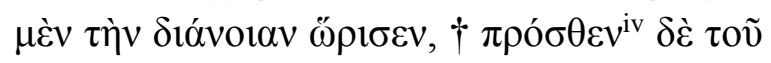

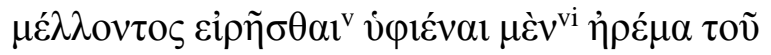

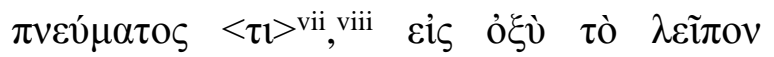

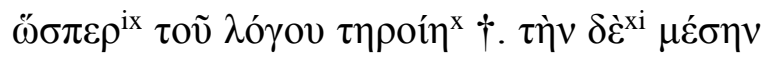

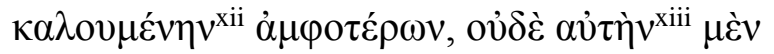

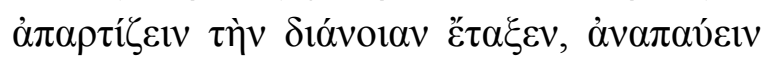

for elided words, and the hypodiastole for those separated from one another, and the straight line that extends under members of a compound, which we thus call the 'hyphen', for words joined together. But I refrain from drawing the shapes of these for people familiar with them.

h) And he also set up the punctuation marks as signs not only for the word but also for the utterance, providing pauses and stopping points for the breath and the voice. And he assigned distinct places and functions to them,

i) [For the sake of brevity we shall mention only the three first and most important ones now. Their sub-parts have been treated in the On periods and cola, and have been recorded by Nicanor son of Hermeias in On Punctuation in General.]

j) positing that the first one always finishes off the thought - the $\sigma \tau \imath \gamma \mu$ í which he puts at the top of the letter-, as if it has power over the utterance and brings the voice down. And he defined the one at the base, this one which we also call the $\dot{\pi} о \sigma \tau \imath \gamma \mu \eta$, as not finishing off the thought, $\dagger$ but as relaxing some of the breath gently before what is about to be said, as if it were to reserve what remains of the utterance for a high pitch $\dagger$. As for the one called the middle of both, this too he did not set up to finish off the thought, but to give a 


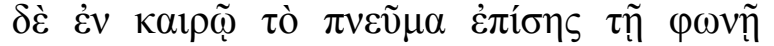

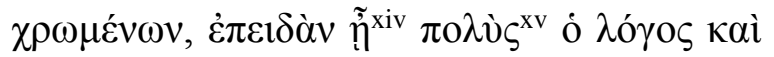
накрós.

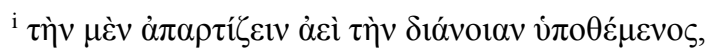

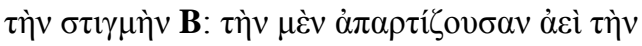

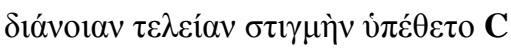

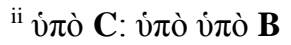

iii $\tau \alpha u ́ \tau \eta v$ ทेv $\mathbf{B}$ : ทेv $\mathbf{C}$

${ }^{\text {iv }} \pi \rho o ́ \sigma \theta \varepsilon v$ dubitanter in apparatu critico M. Schmidt

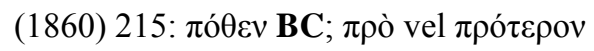
suspicatus est Jacobi apud Lentz (1867) xxxx; pro

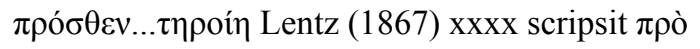

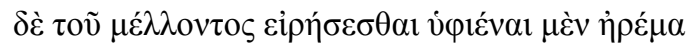

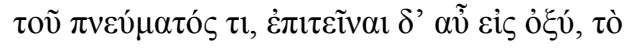

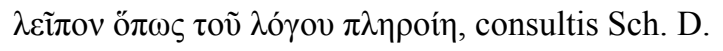
Thr. $\left(\Sigma^{\mathrm{d}}\right) 27.32-28.8$ and $\left(\Sigma^{\mathrm{v}}\right)$ 178. 8-11.

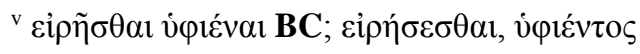
suspicatus est Jacobi

${ }^{\mathrm{vi}} \mu \grave{\varepsilon} \nu \mathbf{C}: \mu \grave{\varepsilon} v \mu \grave{\varepsilon} v \mathbf{B}$

${ }^{\text {vii }} \tau$ ı add. Lentz (1867) xxxx

viii nonnulla verba ante ci̧ ỏ $\xi$ v̀ excidisse suspicatus est M. Schmidt (1860) 215

ix $\dddot{\sigma \pi \varepsilon \rho ~ B C ; ~ o ̈ ~} \pi \omega \varsigma$ suspicatus est Jacobi

$\left.{ }^{\mathrm{x}} \tau \eta \rho o i ́ \eta \mathbf{B C} ; \pi \varepsilon \rho \alpha i ́ v \eta\right\rceil$ suspicatus est Jacobi

xi $\delta \dot{\varepsilon}$ om. B

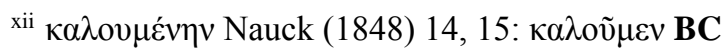

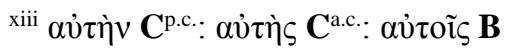

xiv $\tilde{\eta}$ Barker (1820) 190: $\tilde{\eta}$ C: $\tilde{\eta}$ B

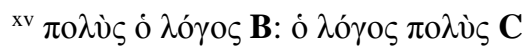

\section{Places in the word where the various signs}

\section{can go:}

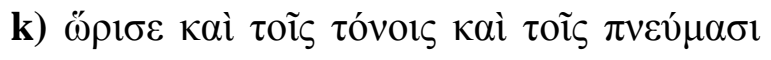

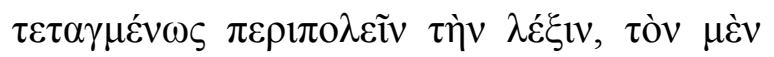

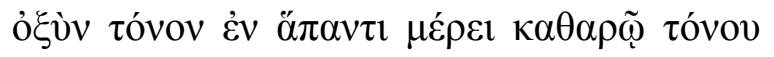

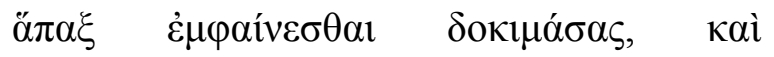

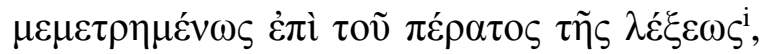

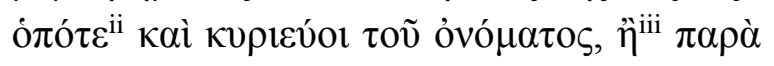

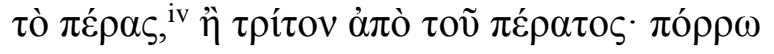

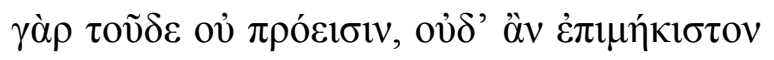

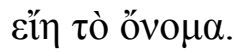

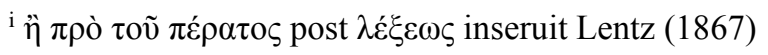
$\mathrm{xxxx}$

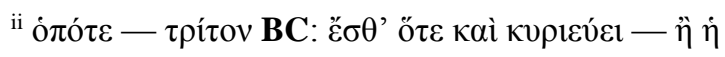
$\tau$ рí $\tau$ dubitanter in apparatu critico M. Schmidt (1860) 215

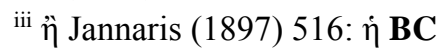

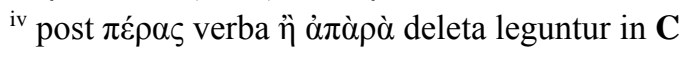

rest to the breath at the critical moment for those using the voice in equal measures (i.e. for those pausing between phrases of equal length), when the utterance is copious and long.

k) And he decreed that accents and breathings should go about speech in an orderly fashion, and sanctioned the appearance of the acute accent once on every word that was intact with respect to its accent, and in a controlled manner on the final syllable of the word-whenever that was indeed the dominant syllable of the word-or next to last, or third from the end. For it will not proceed (i.e. go back) further than this, not even if the word is very long. 


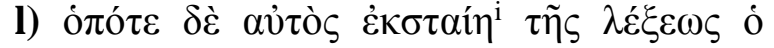

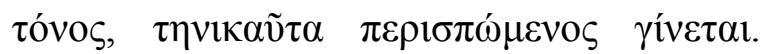

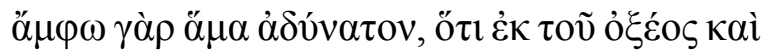

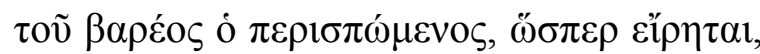

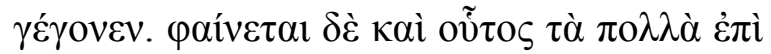

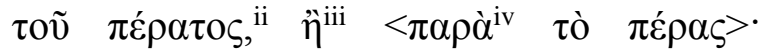

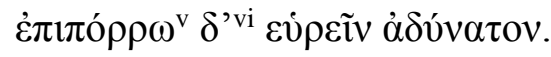

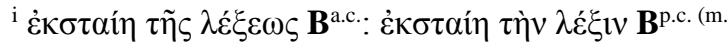

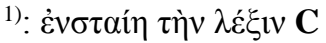

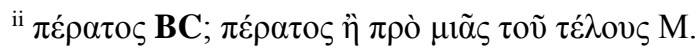
Schmidt (1860) 215 in apparatu critico, coll. Sch. D. Thr. $\left(\Sigma^{v}\right) 127.28$

iii ì om. $\mathbf{C}$

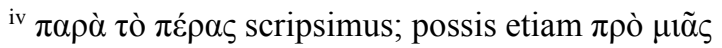

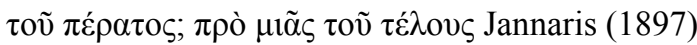
516

v غ̇ंı

vi $\delta$ 'om. $\mathbf{B}$
}

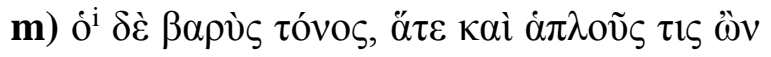

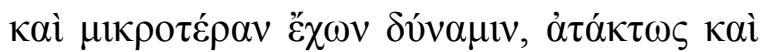

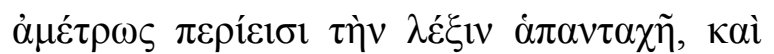

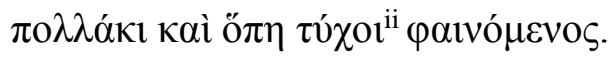

i ó om. C

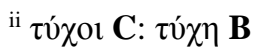

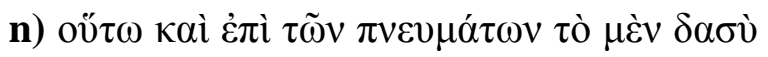

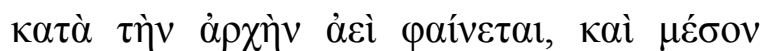

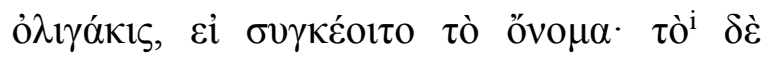

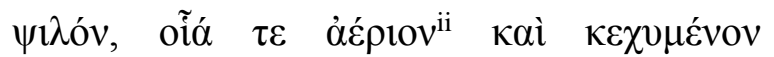

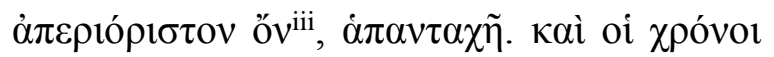

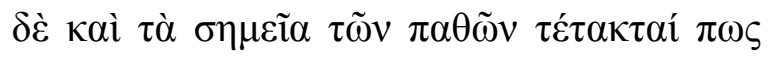

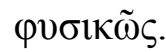

${ }^{\mathrm{i}}$ iò om. B

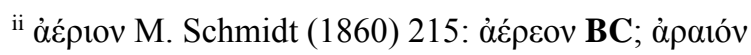
dubitanter K. E. A. Schmidt (1859) 597

iii ôv C: ồ B l) When this accent stands aside from the word, then the accent becomes a circumflex. For both accents together is impossible, because the circumflex is made up of the acute and the grave, as has been said. And this too mostly appears on the final syllable or <the penultimate>; and it is impossible to find it further away (see section 3.5). m) And the grave accent, insofar as it is simple and has less power, will spread itself all over the word in a disorderly and uncontrolled manner, appearing many times and wherever it happens to occur.

n) So in the case of the breathings too the rough one always appears at the beginning, and occasionally in the middle if the word is a compound. But the smooth breathing, intangible and all over the place as it is, being unbounded, (appears) everywhere. And the lengths and the signs for modifications have been arranged more or less as is natural.'

\section{Circumstances of composition}

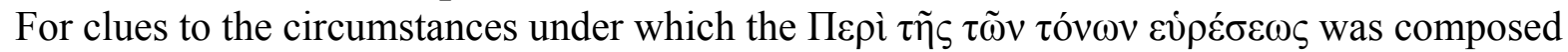
we might consider its syntax, technical terminology and affinities with other known texts; in sections 3.1-3.3 we take these in turn. On the basis of our text's affinities with other known texts, in particular, we shall suggest that our author consulted a source that was in Latin. In sections 3.4 and 3.5 we consider two further features of our text which would be well 
explained on the basis of a Latin source that dealt at least in part with the Latin accent: the use of $\dot{\varepsilon} \pi \alpha \hat{\alpha} \delta \omega$ for 'sing along to' towards the beginning of the text, and (more tentatively) a confusing point in the presentation of possible positions for the circumflex accent towards the end.

\subsection{Syntax}

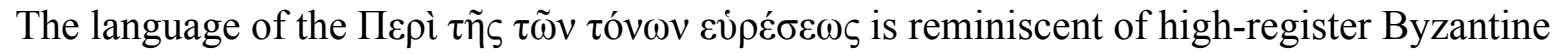
texts. Sentences are convoluted and full of conspicuously elegant features such as optatives, ${ }^{13}$ not all of them used as would be expected in Classical Greek; ${ }^{14}$ an ostentatious application of the rule that a neuter plural subject takes a singular verb (the subject consists of three coordinated nouns, and only the last is a neuter plural); ${ }^{15}$ a noun phrase in the dual; ${ }^{16}$ and copious instances of $\mu \varepsilon \dot{\varepsilon} v \ldots \delta \varepsilon^{17}{ }^{17}$ In addition, we find the following distinctly non-Classical features with parallels in Byzantine texts:

(i) The 'learned' use of middle forms where one would expect actives (see Böhlig (1956) 9495; Browning (1978) 117, 120, 121):

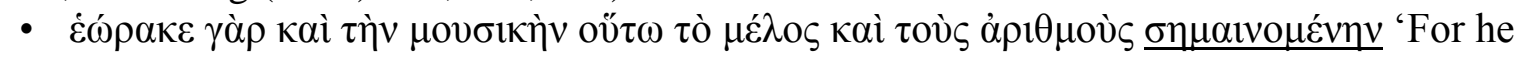
saw that music too indicates the melody and the rhythms like this' (section b)

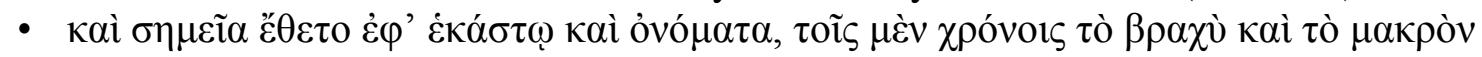

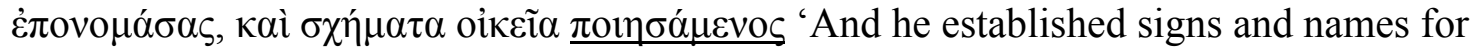
each one, applying "short" and "long" as names for the lengths, and making suitable shapes' (section c)

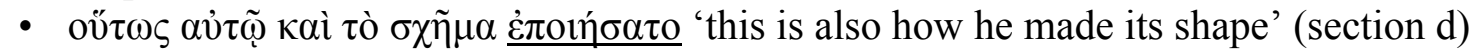

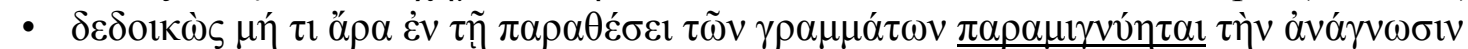
'fearing lest anything in the placing of letters side by side should mix up the reading' (section e)

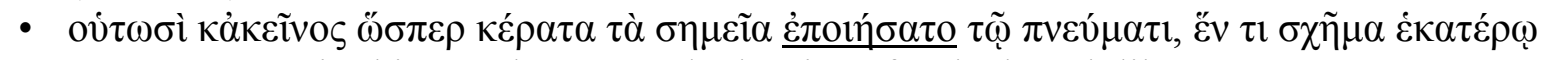

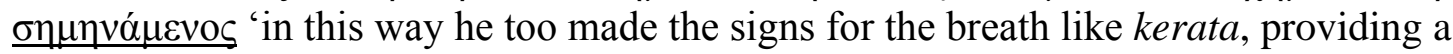
single shape for each' (section $\mathrm{f}$ )

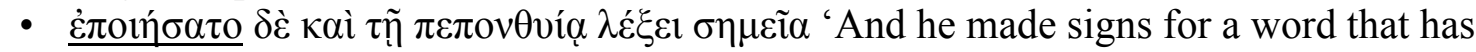
undergone a modification' (section g)

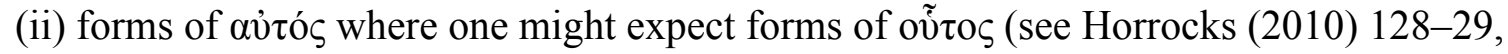
148-49, 247, 250, 295):

- $\alpha$ ờ

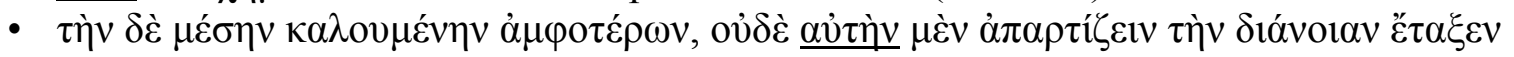
'As for the one called the middle of both, this too he did not set up to finish off the thought' (section $\mathrm{j}$ )

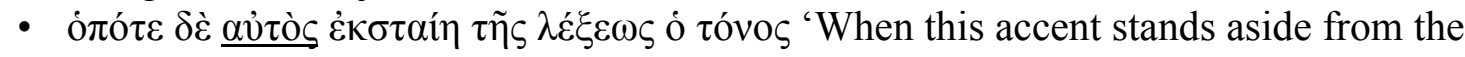
word' (section l)

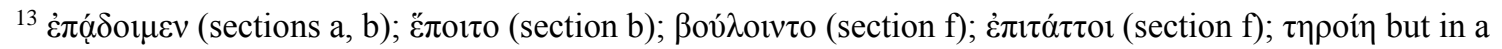

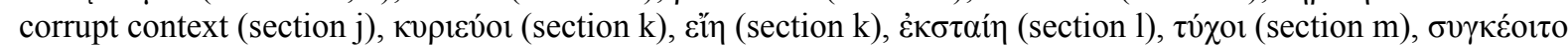
(section $\mathrm{n}$ ).

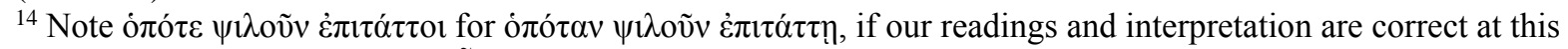

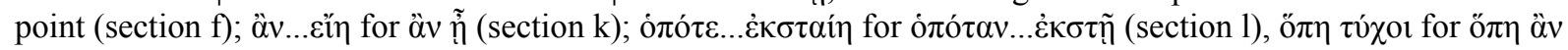

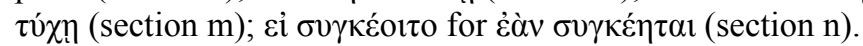

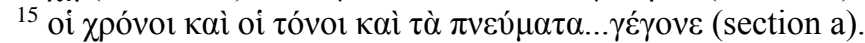

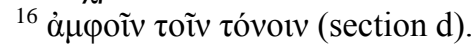

${ }^{17}$ See section $\mathrm{b}$ (four times), section c (three times), section $\mathrm{f}$ (once), section $\mathrm{j}$ (three times, as well as an apparent stand-alone $\mu \varepsilon^{\prime} v$ in a corrupt context), section $\mathrm{n}$ (once). There is perhaps another instance spanning

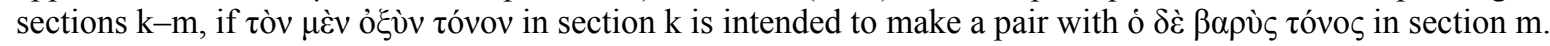
Section i, which we follow Nauck in deleting, also has one occurrence.
} 


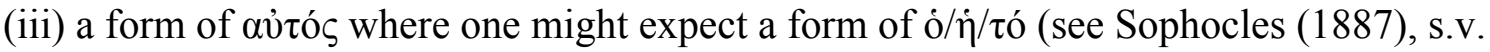

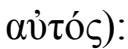

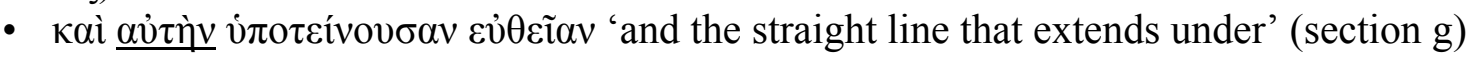

Some instances of these features have been emended away in the past, as our critical apparatus shows, and it is impossible to be sure that all instances go back to the author of the text. Even if we could be confident that they did, none of these features could be used to pinpoint the date of the text very precisely. Nevertheless, when taken together with the author's highly convoluted style, they are more suggestive of a highly educated Byzantine writer than of errors introduced in transmission.

\subsection{Technical terminology}

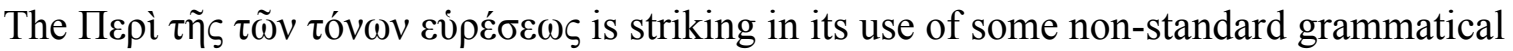
terms, even where the concept denoted is found in other Greek grammatical texts too.

In section $\mathrm{k}$, we are told that Aristophanes of Byzantium decreed that an acute accent should appear once on every word that was $\kappa \alpha \theta \alpha \rho$ s̀ $\tau$ óvov. The point being made here is a

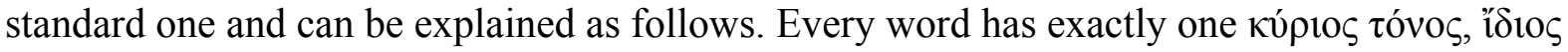

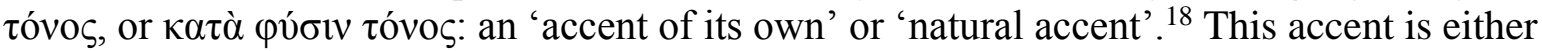
an acute or a circumflex, ${ }^{19}$ but since the circumflex is considered to be made up of an acute and a grave on a single syllable, ${ }^{20}$ every word can be treated as having an acute accent as its

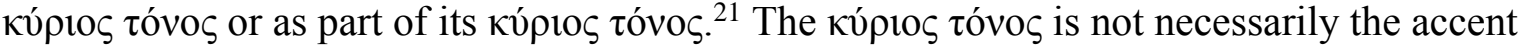

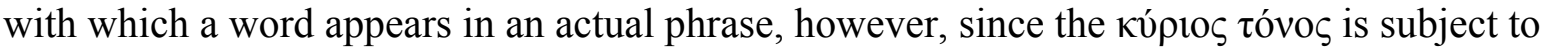
rules that may remove an accent or 'put it to sleep', shift the accent, or add another one. (Thus

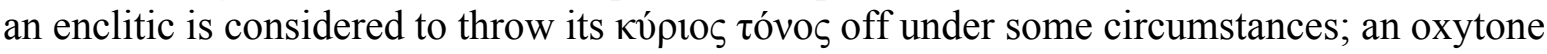
word normally 'puts its accent to sleep' before another non-enclitic word; and under some circumstances a word acquires an extra accent from a following enclitic.) If no such rule has

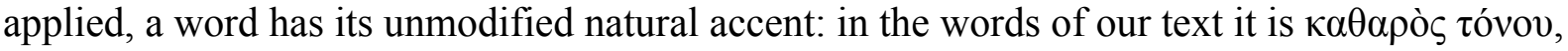
'intact with respect to its accent'. The concept of an unmodified accent is a standard one, and

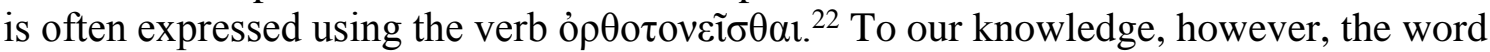
$\kappa \alpha \theta \alpha \rho$ ó $\zeta$ is nowhere else used for an unmodified accent.

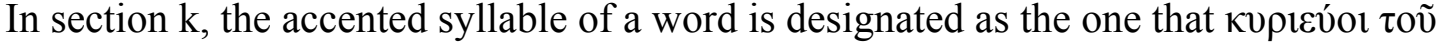
óvó $\mu \alpha \tau \sigma \varsigma$ 'dominates the word'. This phrase is reminiscent of the standard idea that every

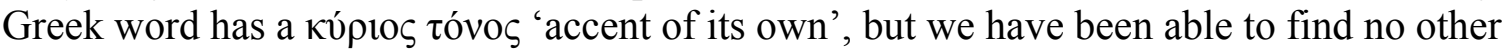

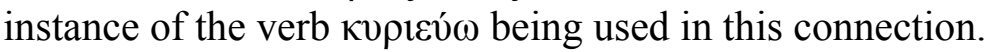

In section 1, we are told that when the acute accent $\dot{\varepsilon} \kappa \sigma \tau \alpha i n \eta \tilde{\eta} \varsigma \lambda \varepsilon_{\varepsilon}^{\xi} \varepsilon \omega \varsigma$ 'stands aside from the word', the accent becomes a circumflex. The point that every word has either an acute accent or a circumflex is a standard one ${ }^{23}$ but the use of an expression for 'stand aside from the word' appears to be unique. We shall return in section 3.3.4 to the idea that an acute accent can 'stand aside from' or vacate a word.

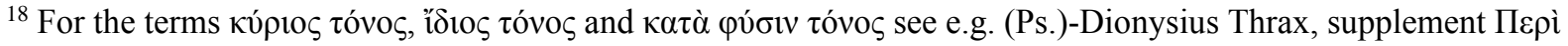
$\pi \rho 0 \sigma \omega \delta i \tilde{\omega}$, 110. 6; Ap. Dysc., Pron. 35. 8, 23.

${ }^{19}$ See e.g. the passages cited at n. 23 below.

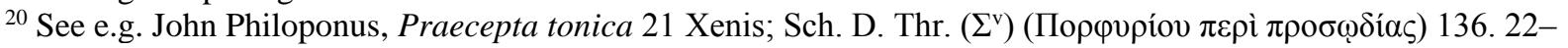
$23 ; 138.26-28$.

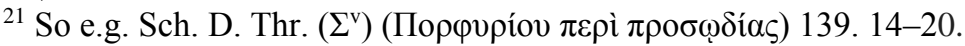

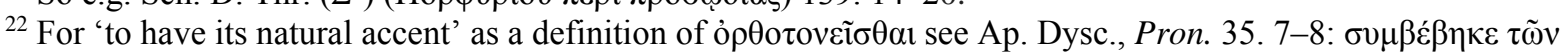

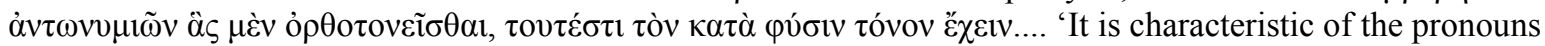
that some are orthotonic, that is to say they have their natural accent...'.

${ }^{23}$ E.g. Ap. Dysc., Pron. 60. 13-14; John Philoponus, Praecepta tonica 20 Xenis.
} 
In sections $\mathrm{k}$ and $\mathrm{l}$ we find a rare use of the expression $\tau$ ò $\pi \varepsilon \dot{\varepsilon} \rho \varsigma_{\varsigma}$ to denote the final syllable

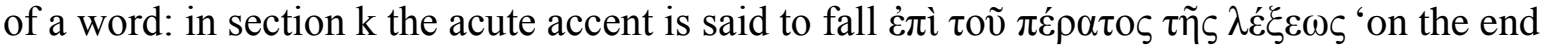

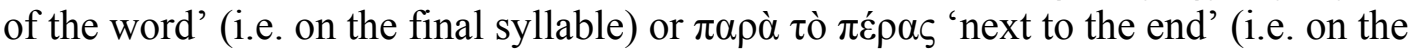

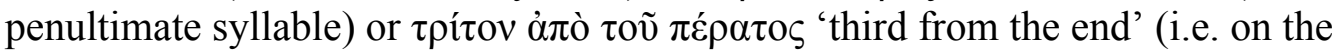
antepenultimate syllable). In section 1 , the information given on possible positions for the circumflex accent (to which we shall return to in section 3.5) is corrupt and confusing, but it is likely from the three-fold distinction between final, penultimate and antepenultimate syllable in section $\mathrm{k}$ that $\tau$ ò $\pi \varepsilon \varepsilon_{\rho} \alpha \varsigma$ denotes the final syllable of the word in section 1 too. In Greek

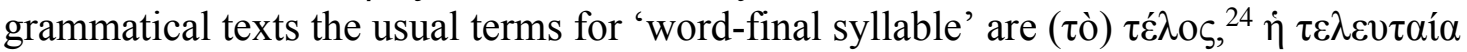
$(\sigma v \lambda \lambda \alpha \beta \dot{\eta}),{ }^{25}$ and $\dot{\eta} \lambda \dot{\eta} \gamma \sigma v \sigma \alpha\left(\sigma v \lambda \lambda \alpha \beta \eta\right.$ ). ${ }^{26}$ The usual terms for 'penultimate syllable' are $\dot{\eta}$ $\pi \rho o ̀ ~ \tau \varepsilon ́ \lambda o v \varsigma ~(\sigma v \lambda \lambda \alpha \beta \eta ́))^{27}$ and $\dot{\eta} \pi \alpha \rho \alpha \lambda \eta ́ \gamma \sigma v \sigma \alpha(\sigma v \lambda \lambda \alpha \beta \eta \dot{)}),{ }^{28}$ and the usual terms for 'antepenultimate syllable' are $\dot{\eta} \tau \rho i ́ \tau \eta ~ \alpha ̉ \pi o ̀ ~ \tau \varepsilon ́ \lambda o v \varsigma ~\left(\sigma v \lambda \lambda \alpha \beta \eta^{29}\right.$ and $\dot{\eta} \pi \rho \circ \pi \alpha \rho \alpha \lambda \eta ́ \gamma \sigma v \sigma \alpha$ ( $\left.\sigma \nu \lambda \lambda \alpha \beta \eta \eta^{3}\right) .{ }^{30}$ Occasional parallels or near-parallels for our text's use of $\tau$ ò $\pi \varepsilon \varepsilon_{\rho} \alpha \varsigma$ can be found in Byzantine authors: ${ }^{31}$ Eustathius suggests that one of the factors allowing metrical lengthening is that the syllable is $\tau$ ò $\pi \dot{\varepsilon} \rho \alpha \varsigma . . \lambda \dot{\varepsilon} \xi \varepsilon \omega \varsigma$, i.e. the last one in the word (passage (1)), and there are occasional instances of similar expressions as glosses for $\pi \tau \tilde{\omega} \sigma 1 \zeta$ in its broad Aristotelian use for any inflectional or derivational ending (e.g. passage (2)): ${ }^{32}$

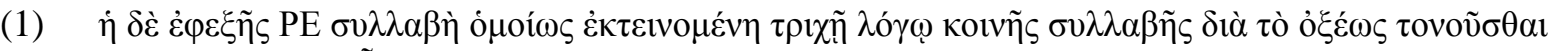

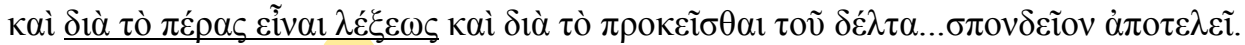

And the next syllable PE (of $\varphi \hat{\imath} \lambda \varepsilon \dot{\varepsilon} \kappa v \rho \varepsilon ́$, $\delta \varepsilon ı$ vó $\tau \varepsilon$ at Homer, Iliad 3. 172), being likewise lengthened on the principle of an anceps syllable in three ways, because it is oxytone and because it is the end of the word and because it precedes delta,...creates a spondee. (Eustathius, In Iliadem 399. 45-400. $2=1.629 .17-20$ Van der Valk)

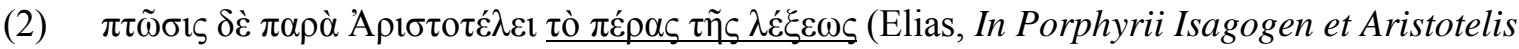
Categorias commentaria 143. 19-20 Busse)

$\pi \tau \tilde{\omega} \sigma ı \zeta$ in Aristotle means the end of the word

Eustathius' use may be motivated by the relevance to him of the boundary between one word and the next, and the use of $\pi \varepsilon \varepsilon^{\prime} \alpha \varsigma$ as a gloss for $\pi \tau \tilde{\omega} \sigma 1 \varsigma$ is apparently motivated by a perceived similarity between the meaning of $\pi \varepsilon \varepsilon^{\prime} \alpha \varsigma$ and the literal meaning of $\pi \tau \tilde{\omega} \sigma 1 \varsigma^{33}$ Yet although occasional parallels or near-parallels can be found, the usage of $\tau$ ò $\pi \varepsilon \dot{\varepsilon} \rho \varsigma_{\varsigma}$ found in our text does not appear to have been widespread at any date.

\subsection{Affinities with other known texts}

\footnotetext{
${ }^{24}$ E.g. [Arcadius] 126. 14 Roussou; John Philoponus, Praecepta tonica 11 Xenis.

${ }^{25}$ E.g. [Arcadius] 297. 7, 300. 4 Roussou; John Philoponus, Praecepta tonica 6 Xenis.

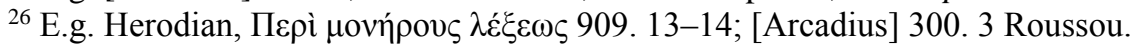

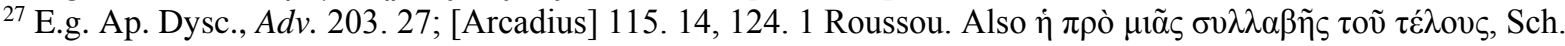
D. Thr. $\left(\Sigma^{v}\right)$ 137. 8.

${ }^{28}$ E.g. Ap. Dysc., Pron. 55. 4; [Arcadius] 139. 20 Roussou; Ep. Hom. alph. $\varepsilon$ 180. 5-6. Also $\dot{\eta} \pi \alpha \rho \alpha \tau \varepsilon ́ \lambda \varepsilon v \tau o \varsigma$ ( $\sigma 0 \lambda \lambda \alpha \beta \eta$ ), e.g. Sch. D. Thr. $\left(\Sigma^{v}\right) 137.6$.

${ }^{29}$ E. g. [Arcadius] 156. 12 Roussou; Ep. Hom. alph. $\alpha$ 271. 18-19.

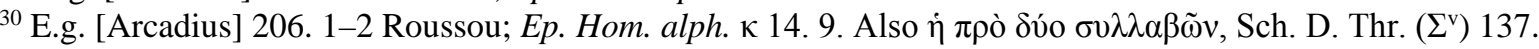
6.

${ }^{31} \mathrm{We}$ are indebted to one of the journal's anonymous referees for drawing our attention to these parallels.

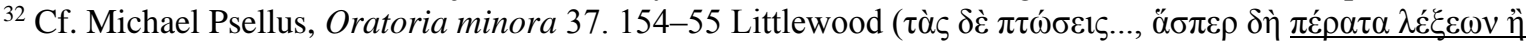

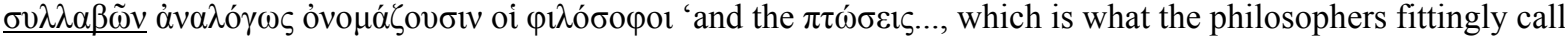

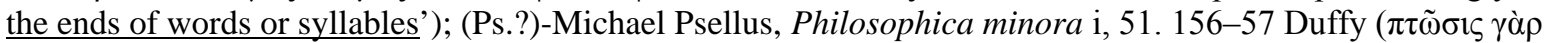

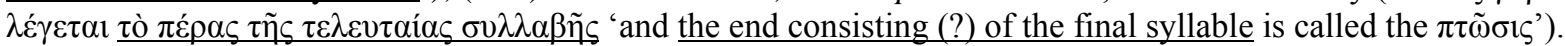

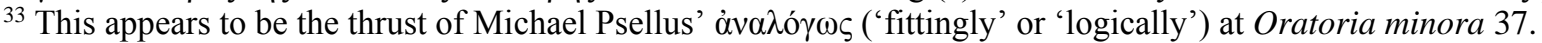
154-55 Littlewood, quoted in n. 32.
} 
Our text has been said to derive from the tradition of commentaries on the Té $\chi v \eta \gamma \rho \alpha \mu \mu \alpha \tau \iota \kappa \eta$

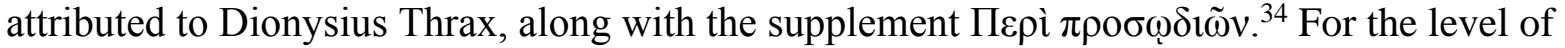
interest in the history of the prosodic signs, however, a Latin text has been compared: the 'De accentibus' section of a commentary on Donatus' Ars maior whose author goes under the name of 'Pseudo-Sergius' ${ }^{35}$ Certain points of contact between our text and Pseudo-Sergius could indeed be explained on the basis of a similar source. In particular, the term o $\xi v \beta \alpha \rho \varepsilon i ̃$ (or ỏ $\xi v \beta \alpha \rho v ́ \varsigma$ ) for 'circumflex' occurs only in these two texts, and Pseudo-Sergius provides the best parallel for our text's point that the grave accent is naturally capable of spreading itself out over more of the word than the acute or circumflex. ${ }^{36}$ However, further features of content and terminology suggest that the author of our text himself consulted a Latin source. In sections 3.3.1-3.3.5 we discuss points that do not appear in Pseudo-Sergius' section 'De accentibus', just mentioned, but whose best parallels again come from Latin rather than Greek sources.

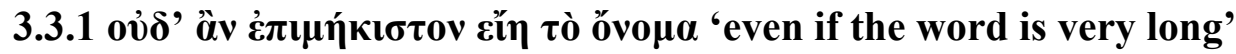

In section $\mathrm{k}$, our text has it that the accent cannot fall further from the end of a word than the antepenultimate syllable, 'even if the word is very long'. While this point may seem unremarkable, it is in Latin grammatical texts on the Latin accent that we otherwise find allusions to possible word length used to emphasise the limits on where the word accent can fall:

(3) circumflexus autem, quotlibet syllabarum sit dictio, non tenebit nisi paenultimum locum. And the circumflex - no matter how many syllables a word consists of - will only occupy the penultimate position. (Donatus, Ars maior 609. 8-9 Holtz = GL iv. 371. 5-6)

(4) in Graecis itaque dictionibus cum acutus tria loca teneat, ultimum paenultimum antepaenultimum, ultra numquam (neque enim refert plurium syllabarum esse partem orationis), apud Latinos duo tantum loca tenet, paenultimum et antepaenultimum; circumflexus autem, quotlibet syllabarum sit dictio, non tenebit nisi paenultimum locum. (Diomedes, Ars, GL i. 431. 10-14)

Whereas the acute occupies three places in Greek words - the final syllable, the penultimate and the antepenultimate, but never beyond that (nor does it matter if the word consists of more syllables) - for Latin speakers it occupies two places only, the penultimate and antepenultimate. And the circumflex will not occupy any place but the penultimate, no matter how many syllables the word consists of.

(5) nam si quantarumuis sermo sit syllabarum, circumflexus non tenebit ultra nisi paeneultimum locum. ([Sergius], De littera, de syllaba, de pedibus, de accentibus, de distinctione, GL iv 482. 20-21)

For if a word consists of any number of syllables, the circumflex will not occupy any place further back apart from the penultimate.

(6) circumflexus accentus in disyllabis uel in trisyllabis uel in quantouis numero syllabarum paeneultimum sibi tantum uindicat locum... ([Sergius], De littera, de syllaba, de pedibus, de accentibus, de distinctione, $G L$ iv 483. 11-12)

In disyllabic or trisyllabic words, or in any number of syllables, the circumflex claims for itself only the penultimate place.

\footnotetext{
${ }^{34}$ M. Schmidt (1860) 211; cf. Villoison (1783) 117; Pfeiffer (1968) 179.

${ }^{35}$ For the 'De accentibus' section see [Sergius], In Donati Artem maiorem, GL iv, pp. 524-33. For the comparison with our text see Lentz (1867) xxxviii.

${ }^{36}$ [Sergius], In Donati Artem maiorem, GL iv. 532. 12-14 Keil.
} 
Occasional comments on possible word length are found in Greek discussions of the Greek accent, but the contexts are quite different. In passage (7), Dionysius of Halicarnassus is not discussing possible positions for the accent but noting that no matter how long a word is, only one of its syllables has an acute accent. ${ }^{37}$ In passage (8), and in similar discussions in Choeroboscus ${ }^{38}$ the author is not emphasising the limits to where the word accent can fall but offering an explanation for the existence of these limits in the first place.

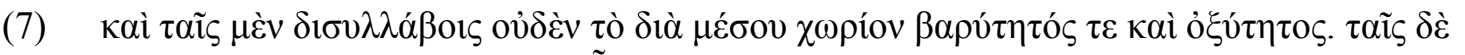

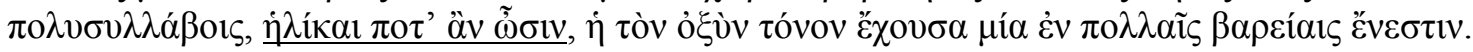
(Dionysius of Halicarnassus, De compositione verborum 11.17)

Now in words of two syllables (i.e. of which one has an acute and one a grave) there is no space between the high pitch and the low pitch. But in polysyllables, however many syllables there are, the one with the high pitch is among many low-pitched ones.

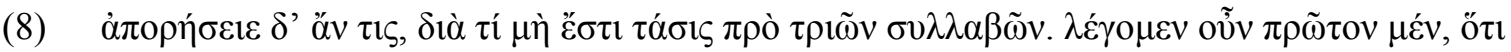

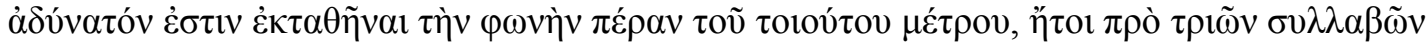

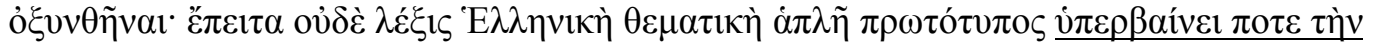

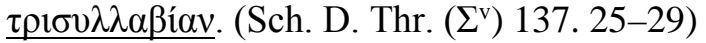

And someone might ask why there is no accent more than three syllables back. We say firstly that it is impossible for the voice to be stretched out beyond this measure, that is to say to be made acute more than three syllables back. Secondly, no simplex Greek word that is a base form and underived ever exceeds the compass of three syllables.

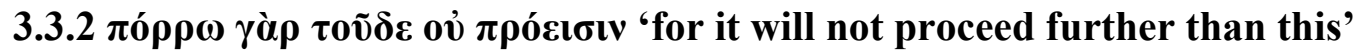

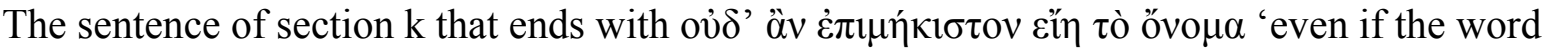

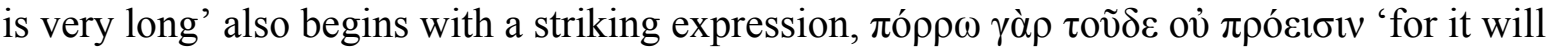
not proceed (i.e. go back) further than this'. The point that an accent cannot fall further from the end of the word than the antepenultimate syllable is widespread in Greek grammatical

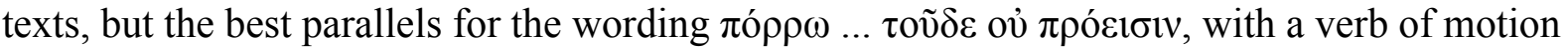
and an adverb meaning 'further', come from Latin grammatical texts:

(9) et hoc plus non ascendit accentus, sed aut in finali est aut in paenultima aut in tertia a fine. (Pompeius, Commentum artis Donati, GL v. 127. 21) ${ }^{39}$

And the accent does not go up further than this, but is either on the final syllable or on the penultimate or on the third from the end.

(10) accentus autem conputantur non a prioribus syllabis, sed ab ultimis, id est retrorsum, nec possunt ascendere nisi usque ad tertiam syllabam a fine. (Servius, Comm. in Donatum, GL iv. 426. 20-22)

And accents are calculated not from initial syllables but from final ones, that is to say backwards, nor can they go up except as far as the third syllable from the end.

(11) ...necesse est ut trisyllaborum rationem omnia posasyllaba sequantur, eo quod usque ad tres syllabas a fine ascendit accentus... (Servius, Comm. in Donatum, GL iv. 426. 38-427. 1)

It is necessary for all words of however many syllables to follow the principles of trisyllabic words, because the accent goes up to three syllables from the end.

\footnotetext{
${ }^{37}$ In context, the notion of a syllable with an acute accent includes that of a syllable with a circumflex accent, with the circumflex considered to consist of an acute and a grave on a single vowel (cf. the passages cited in $n$. 20).

${ }^{38}$ Passage (15) and the passages cited in n. 40.

${ }^{39}$ This passage also contains several further instances of the verb ascendere. Compare also Donatus Ortigraphus, paraphrasing Pompeius in medieval Ireland (Ars grammatica, §De accentu 70-71 Chittenden): plus non ascendit accentus nec apud Grecos nec apud Latinos 'The accent does not go up further, neither for Greeks nor for Latin speakers'.
} 
(12) ab ea enim quae est a fine tertia ulterius non potest acutus ascendere. (Audax, De Scauri et Palladii libris excerpta, GL vii. 359. 21-22)

For the acute cannot go up further beyond the syllable that is third from the end.

In Greek texts we occasionally find a different adverb meaning 'further', $\pi \varepsilon \rho \alpha \imath \varepsilon \dot{\varepsilon} \rho \omega$, used without a verb of motion to convey that the accent cannot fall further from the end of the word than the antepenultimate syllable (passages (13) and (14)). When explaining why there are limits to the distance from the end of the word where the Greek accent can fall, Choeroboscus (e.g. passage (15)) uses the verb $v \pi \varepsilon \rho \beta \alpha i v \omega$ in its widespread metaphorical sense 'exceed', both for words exceeding a certain compass and for accents exceeding or going beyond the same limits. ${ }^{40}$

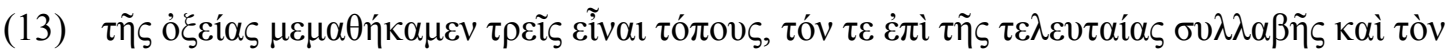

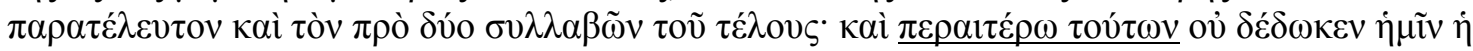

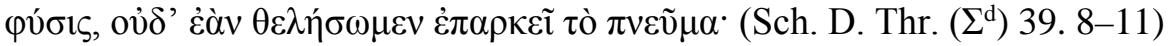

We have learnt that there are three places for the acute accent: the one on the final syllable, the penultimate one and the one two syllables before the end. And nature has not granted to us (the placement of an accent) further (back) than these (places).

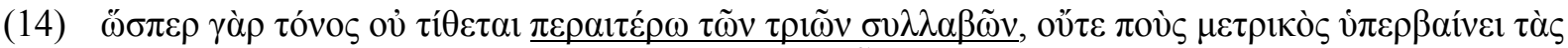

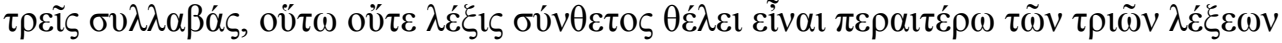

(Etymologicum magnum 459.9-12)

For just as the accent is not placed further (back) than three syllables, nor does a metrical foot go beyond three syllables, so a compound word does not tend to be beyond three words (i.e. a compound word is not usually composed of more than three simplex words).

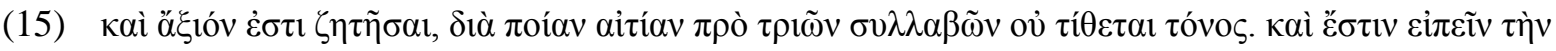

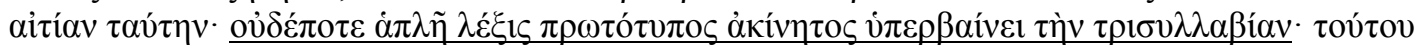

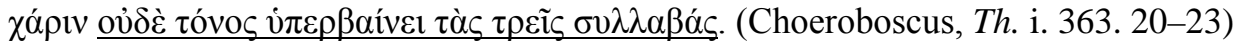

And it is worth investigating the reason why an accent is not placed more than three syllables back. And it is possible to give the following reason: a simplex word that is underived and uninflected never exceeds the compass of three syllables. For this reason the accent too does not go beyond three syllables.

The Latin texts quoted above provide the closest parallels we have found for the more striking

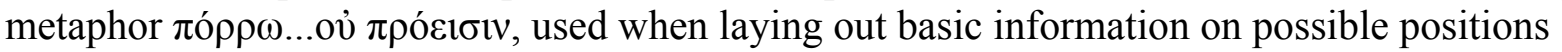
of the accent.

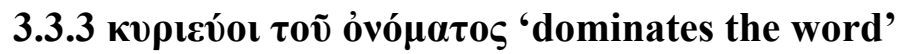

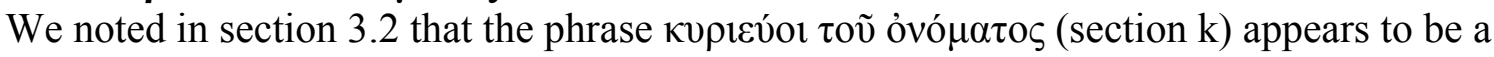
unique way of designating the accented syllable in Greek. In Latin grammatical texts, however, we find the idea that the accent 'rules the word' and the idea that the accented syllable 'has more power' than other syllables: ${ }^{41}$

\footnotetext{
${ }^{40}$ So also Choeroboscus, Th. i. 363. 33, 363. 37, 386. 2, 386. 3.

${ }^{41}$ Compare also the following expressions, from Sedulius Scottus in medieval Ireland: ipsa syllaba quae accentu

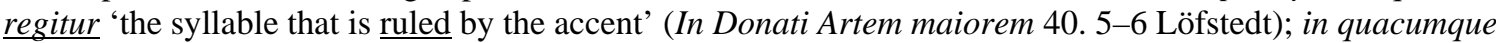
syllaba uel acutus uel circumflexus regnat 'in whatever syllable the acute or circumflex reigns' (41. 66-67 Löfstedt); in eadem dictione in quacumque syllaba nec acutus nec circumflexus regnat grauis ponatur '(that) a grave is placed on any syllable of the same word in which neither an acute nor a circumflex reigns' (42. 82-84 Löfstedt); non solum grauis ultimam et paenultimam, sed et acutus antepaenultimam regit 'not only does the grave rule the final and penultimate syllables (of the word anima), but the acute also (rules) the antepenultimate' (42. 96-98 Löfstedt); nam in paenultima huius nominis syllaba circumflexus accentus regnat 'For in the penultimate syllable of this word (i.e. malesānus) the circumflex accent reigns' (46. 25-27 Löfstedt). Compare
} 
(16) Accentus est acutus uel grauis uel inflexa elatio orationis uocisue intentio uel inclinatio acuto aut inflexo sono regens uerba. (Diomedes, Ars, GL i. 430. 29-30)

Accent is an acute, grave, or circumflex elevation of speech or tension or inclination of the voice, ruling words with an acute or circumflex sound.

(17) et quem ad modum anima nostra in toto corpore ipsa plus potest, sic etiam illa syllaba plus sonat in toto uerbo, quae accentum habet. ergo illa syllaba, quae accentum habet, plus sonat, quasi ipsa habet maiorem potestatem. (Pompeius, Commentum artis Donati, GL v. 126. 30-33) And in the way that our soul has the most power in the whole body, so too the syllable that has the accent gives the most sound in the whole word. Thus the syllable that has the accent gives more sound, as if it has greater power.

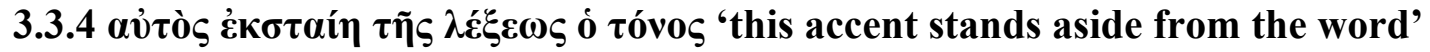

In section 3.2 we saw that the idea of a word that does not have an acute accent (and therefore has a circumflex) is expressed with the help of a unique use of one of the intransitive forms of

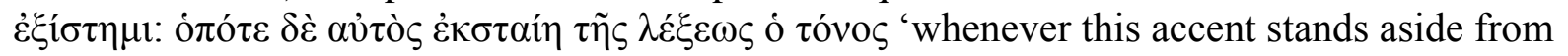
the word' (section 1). The idea that an accent vacates a syllable, allowing another accent to take possession, is found in the Latin tradition in Cledonius' commentary on Donatus:

(18) ... loca quae circumflexus aut acutus dimiserit, grauis possidet...non sibi uindicat locum, sed dimissum ab aliis possidet

... the grave occupies the places that the circumflex or acute has abandoned...(the grave) does not claim a place for itself, but occupies the one abandoned by others (Cledonius, 37. 12-13, 14-15 Bernetti $=G L$ v. 32. 8-9, 10)

While this is the only close parallel we are aware of up to late antiquity, in the Latin tradition we find further late antique instances of the metaphor that an acute or circumflex 'occupies' or 'lays claim to' a word or syllable ${ }^{42}$ - a metaphor that does not appear explicitly in our Greek text but is implicit in the idea that one accent 'stands aside' for another. The idea that an accent may 'abandon' a particular syllable appears again in medieval Ireland, in Donatus Ortigraphus (passage (19)), and was perhaps available in principle wherever the metaphor of accents 'occupying' syllables was familiar.

(19) DISCIPULUS: cur accentus ascendit aliquando usque ad antepenultimam, deserens ${ }^{43}$ penultimam, cum secundum regulam utramque syllabam potest habere?

PUPIL: Why does the accent sometimes go up as far as the antepenultimate syllable, abandoning the penultimate, when according to the rule either syllable can have it? (Donatus Ortigraphus, Ars grammatica, §De accentu 72-74 Chittenden)

\footnotetext{
also, with a verb of a different meaning, 'interealoci', cuius antepaenultimam syllabam acutus fastigiat accentus '(the word) interealoci, whose antepenultimate syllable the acute accent tops' (46. 31-32 Löfstedt).

${ }^{42}$ Omnis sermo necesse est ut aut acutum habeat aut circumflexum: nullus est sermo, qui sine istis sit: si non habet acutum, circumflexum habet; si non habet circumflexum, acutum habet. et grauis ubi erit, si uel ille uel ille sibi sermonem uindicat? 'It is necessary for every word to have either an acute or a circumflex. There is no word without these. If it does not have an acute, it has a circumflex; if it does not have a circumflex, it has an acute. And where will the grave be, if either that accent or that one claims the word for itself?' (Pompeius, Commentum artis Donati, GL v. 126. 13-16); ...non sibi specialem uindicat partem, non habet propriam '(the grave accent) does not claim a special part (of the word) for itself, it does not have its own' (Pompeius, Commentum artis Donati, GL v. 126. 25-26); circumflexus accentus in disyllabis uel in trisyllabis uel in quantouis numero syllabarum paeneultimum sibi tantum uindicat locum... 'In disyllabic or trisyllabic words, or in any number of syllables, the circumflex claims for itself only the penultimate place' ([Sergius], De littera, de syllaba, de pedibus, de accentibus, de distinctione, GL iv 483. 11-12).

${ }^{43}$ Chittenden prints deferens, but the correction to deserens is incorporated into the electronic version of the Brepols Library of Latin Texts (http://www.brepolis.net).
} 
Passage (20) shows the closest parallel we have been able to find in Greek, but the context here is quite different. In a discussion of the relationship between o $\varphi v \omega$ 'unawares, suddenly' and $\dot{\alpha} \varphi \alpha v \tilde{\omega} \varsigma$ 'obscurely', Apollonius Dyscolus has said that an adverb in $-\varsigma$ keeps the accent of the genitive plural of the word from which it is considered derived: hence $\dot{\alpha} \varphi \alpha v \tilde{\omega} \varsigma$ beside $\dot{\alpha} \varphi \alpha v \tilde{\omega} v$, genitive plural of $\dot{\alpha} \varphi \alpha v \eta ́ \varsigma$ ('obscure'). But we learn that the adverb may come to differ from the genitive plural through a change such as the loss of a vowel, and such a change prompts both the accent and the $-\varsigma$ to 'depart':

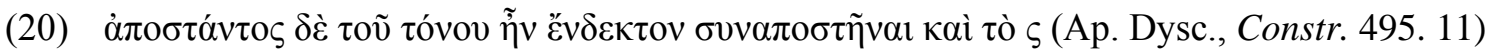
For with the accent departing, it was admissible for the $\varsigma$ to depart as well.

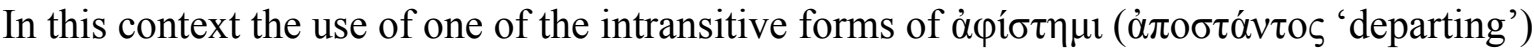
appears to be prompted by the parallel being drawn between the 'departure' of the accent of the base word and the departure of the final $-\varsigma$. What we do not have here is the idea that an acute, circumflex, or grave accent claims a word or syllable for itself, or leaves a word or syllable free for a different accent (acute, circumflex, or grave) to occupy.

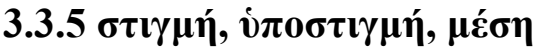

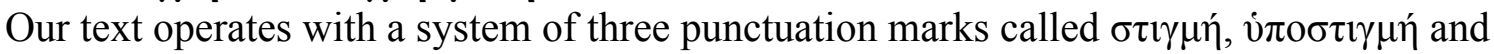

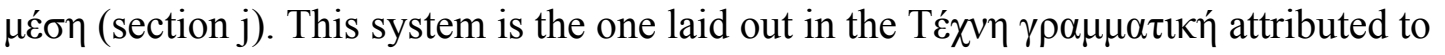
Dionysius Thrax, but there the three marks are presented in the order $\sigma \tau \imath \gamma \mu \eta$ (or $\tau \varepsilon \lambda \varepsilon i \alpha$

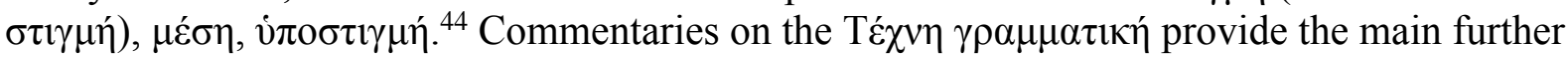
discussions of this system in the Greek tradition, and they too use the order $\sigma \tau \imath \gamma \mu \eta$ (or $\tau \varepsilon \lambda \varepsilon i ́ \alpha$

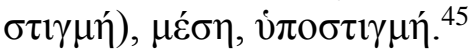

In the Latin grammatical tradition, on the other hand, the same three punctuation marks are often presented in the order distinctio, subdistinctio, media distinctio (or mora), the Latin

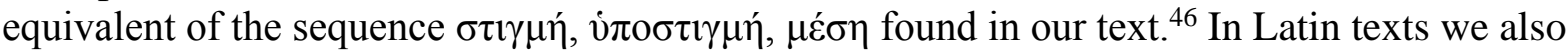
find the order distinctio, media distinctio, subdistinctio (corresponding to the standard Greek order) ${ }^{47}$ and Isidore of Seville even has the reverse order subdistinctio, media distinctio, distinctio. ${ }^{48}$ As far as we can discover, however, only Latin texts provide parallels for our

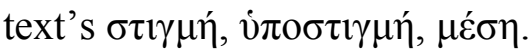

\section{4. 'Singing along to our speech'}

Our text begins with a statement of the purposes for which Aristophanes of Byzantium created the signs for quantities, accents and breathings: to resolve ambiguities and convey the

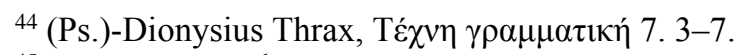

45 Sch. D. Thr. $\left(\Sigma^{\mathrm{d}}\right)$ 24. 8-25. 22; $\left(\Sigma^{\mathrm{v}}\right)$ 176. 16-177. 18; $\left(\Sigma^{\mathrm{m}}\right)$ 312. 5-32, 314. 13-14; $\left(\Sigma^{\mathrm{l}}\right)$ 479. 19-480. 2.

${ }^{46}$ See Diomedes, Ars, GL i. 437.9-439. 9; Donatus, Ars maior 612. 1-7 Holtz = GL iv. 372. 14-22; Servius, Comm. in Donatum, GL iv. 427. 36-428. 4; [Sergius], De littera, de syllaba, de pedibus, de accentibus, de distinctione, GL iv. 484. 22-30 (but the first mention of the three signs here follows the order distinctio, media distinctio, subdistinctio), and from the Middle Ages see the Excerpta Vaticana de positura, de chria, de poemate, de versu, de accentibus, GL vi. 273. 1-6; Julian of Toledo, Ars grammatica II. 13. 1-4; Sedulius Scottus, In Donati Artem maiorem, 51. 16-52. 49 Löfstedt; Murethach, In Donati Artem maiorem I. 43. 1-45. 38 Holtz. For explicit comments on Donatus' order see Cassiodorus, De orthographia, GL vii. 145. 30-146. 16; Sedulius Scottus, In Donati Artem maiorem, 52. 50-59 Löfstedt; Murethach, In Donati Artem maiorem I. 44. 12-19 Holtz.

${ }^{47}$ See [Sergius], In Donati Artem maiorem, GL iv. 533. 28-534. 4; Pompeius, Commentum artis Donati, GL v. 133. 3-11; Audax, De Scauri et Palladii libris excerpta, GL vii. 324. 12-18; Dositheus, Grammatica 5 Bonnet = GL vii. 380. 6/7-13/17; [Victorinus], De arte grammatica, GL vi. 192. 7-13. Cf. also Diomedes, Ars, GL i. 437. 15-19 (where the order distinctio, media distinctio, subdistinctio appears briefly within a discussion that otherwise follows the order distinctio, subdistinctio, media distinctio).

${ }^{48}$ Isidore of Seville, Etymologiae 1. 20. 1.
} 
melody of the voice, $\dot{\omega} \varsigma \dot{\varepsilon} \grave{\alpha} v \dot{\varepsilon} \pi \alpha \underline{\alpha} \delta o u \mu \varepsilon v \varphi \theta \varepsilon \gamma \gamma o ́ \mu \varepsilon v o l$ 'as if we were to sing along to our speaking'.

The idea that quantities, accents and breathings are sung along to syllables is implicit in the Greek word $\pi \rho \circ \sigma \omega \delta i \alpha^{\prime}$ 'prosody', an abstract noun derived from $\pi \rho \circ \sigma \alpha \underline{\alpha} \delta \omega$ 'sing to'.

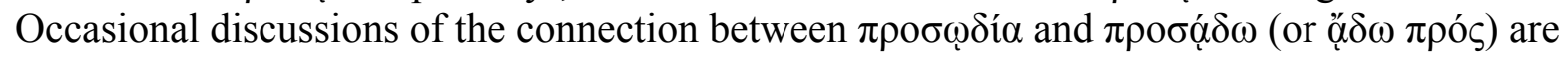
found in Greek, in Byzantine commentaries on Aristotle's Sophistici elenchi and in commentaries on Dionysius Thrax. ${ }^{49}$ But our text is unique in using the verb غ̇ $\pi \alpha \alpha \omega$ in a discussion of prosody rather than $\pi \rho \circ \sigma \alpha \alpha \delta \omega$, although the noun $\pi \rho 0 \sigma \omega \delta i ́ \alpha$ would make $\pi \rho \circ \sigma \alpha \underline{\alpha} \delta \omega$ the more obvious verb.

If we are right to suggest that the author of our text consulted a source that was in Latin, his use of $\dot{\varepsilon} \pi \alpha \alpha \delta \omega$ may be a further reflection of this history. Discussion of the origins and meaning of the word accentus plays a much more central role in the Latin grammatical tradition than discussions of the word $\pi \rho 0 \sigma \omega \delta$ í $\alpha$ do in the Greek grammatical tradition. In several texts we are told that $a d$ - is the equivalent of Greek $\pi \rho 0 \sigma-$, and -centus (from cano 'sing') is the equivalent of $-\omega \delta$ í $\alpha$ (from $\alpha \alpha \delta \omega$ 'sing'), ${ }^{50}$ a point that already focusses the attention on the component parts of each word and their meanings. Passages (21)-(23) go further in bringing out the idea that accentus is a melody to which syllables or speech are sung:

(21) 'accentus' est dictus ab 'accinendo', quod sit quasi quidam cuiusque syllabae cantus. apud

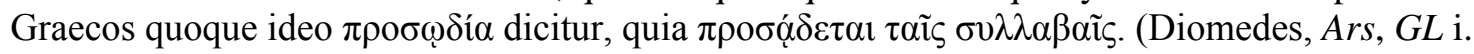
431. 1-3)

accentus comes from accino, which is (as it were) a certain melody for each syllable. Among

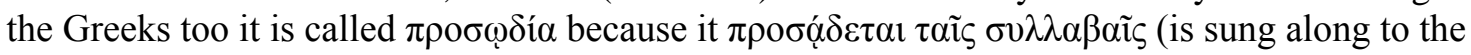
syllables).

(22) 'accentus' autem est quasi 'adcantus' dictus, quod ad cantilenam uocis nos facit agnoscere syllabas. (Servius, de finalibus, GL iv. 451. 10-12)

And accentus is called (as it were) adcantus, because it makes us recognise syllables to the song of the voice.

(23) et est accentus, ut quidam putauerunt, anima uocis et seminarium musices, quod omnis modulatio ex fastigiis grauitateque componitur, ideoque accentus quasi adcantus dictus est. (Martianus Capella, De nuptiis iii. 268)

And accent, as some have thought, is the soul of speech and the nursery of music, because every melody is composed of high points and low, and hence accent is called (as it were) adcantus.

\footnotetext{
${ }^{49}$ See Paraphrasis in Sophisticos elenchos 8.16 Hayduck; [Alexandri] in Sophisticos elenchos commentarium 32. 22-23 Wallies; Scholia ex Commentario I in Sophisticos elenchos extracta 18. 5-8 Ebbesen; Sch. D. Thr. $\left(\Sigma^{\mathrm{l}}\right)$ 454. 12-13; Sch. D. Thr. $\left(\Sigma^{\mathrm{v}}\right)$ 136. 3-4, 8-11. (Cf. also Sch. D. Thr. $\left(\Sigma^{v}\right)$ 150. 33-34, 151. 8, where $\hat{\phi} \delta \eta \dot{~ i s ~}$ interpreted as 'word'.) In the partial Greek translation of his grammar of Latin, Dositheus (Grammatica 2 Bonnet

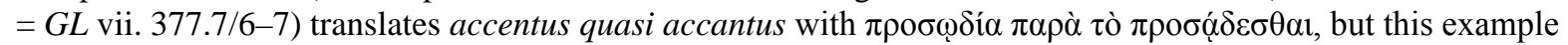
belongs with the Latin texts cited in $\mathrm{n} .50$.

${ }^{50}$ See Servius, Comm. in Donatum, GL iv. 426. 7-9: 'accentus' dictus est quasi adcantus secundum Graecos,

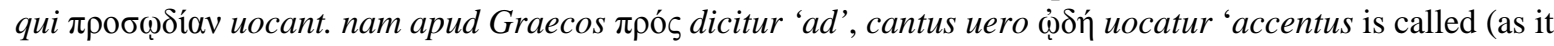
were) adcantus following the Greeks, who call it $\pi \rho 0 \sigma \omega \delta i ́ \alpha$. For among the Greeks ad is $\pi \rho$ ó, and cantus is

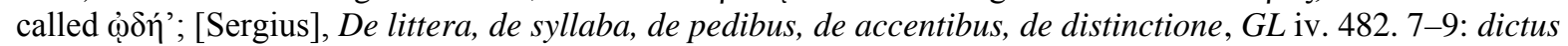
autem 'accentus' est quasi 'adcantus' iuxta Graeci nominis interpretationem, quod 'prosodia' dicitur Latine 'adcantus' 'And accentus is called (as it were) adcantus, according to the meaning of the Greek word, because $\pi \rho 0 \sigma \omega \delta$ ía is adcantus in Latin'; Pompeius, Commentum artis Donati, GL v. 125. 35-126. 2: Graeci 'prosodias' dicunt accentus hac ratione: 'pros' dicunt 'ad', 'cantum' dicunt 'oden'. uerbum de uerbo Latini expresserunt, ut dicerent 'prosodias' 'accentus' 'The Greeks call accents $\pi \rho 0 \sigma \omega \delta$ íal on the following basis: they say $\pi \rho \rho^{\prime} \varsigma$ for $a d$,

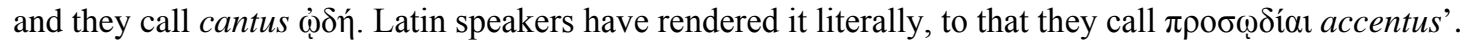


With the appearance of $\dot{\varepsilon} \pi \alpha \dot{\delta} \delta \omega$ in our text, the notion of 'singing along to our speaking' has been de-coupled from the noun $\pi \rho 0 \sigma \omega \delta i$, which does not make an appearance in this text. If we are right to suggest that the author of our text consulted a source that was in Latin, this decoupling may have happened under the influence of Latin discussions that focus on the Latin word accentus, from ad-cantus, derived from ad-cano or accino, which the author of our text rendered in Greek as غ̇ंđó $\delta \omega$.

\subsection{The circumflex 'mostly' occurs on the final syllable}

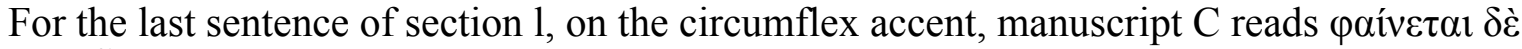

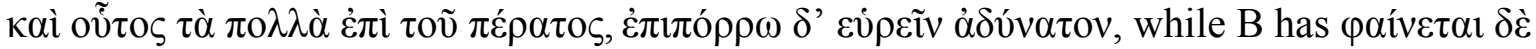

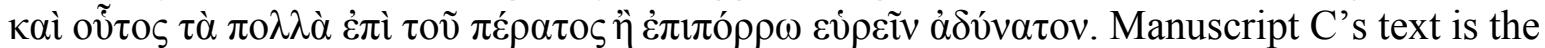
more comprehensible, but it makes a surprising statement: 'And this too (i.e. the circumflex) mostly appears on the final syllable, and it is impossible to find it further away'. We seem to be missing the possibility that the circumflex can appear on the penultimate syllable, and some corruption has evidently occurred where the texts of the two manuscripts differ. We

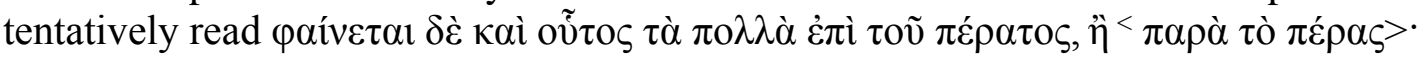

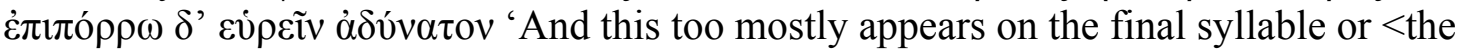
penultimate>; and it is impossible to find it further away'. ${ }^{51}$ While this statement is less

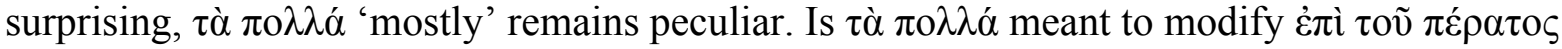

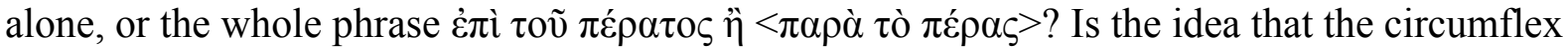
'mostly' falls on the final syllable (and occasionally on the penultimate), or that the circumflex mostly falls on the final or penultimate syllable (and occasionally somewhere else)? The second possibility can probably be ruled out, since the Greek circumflex only ever appears on the final or penultimate syllable: $\tau \dot{\alpha} \pi 0 \lambda \lambda \alpha$ ' would be an odd way to say 'always'. In favour of the first possibility it can be said that the Greek circumflex does indeed appear more often on the final syllable than the penultimate, not least owing to forms of the definite article like $\tau \tilde{\eta} \varsigma$ or $\tau \tilde{\omega} \nu$ (in our text itself there are 103 circumflexes on final syllables and 45 on

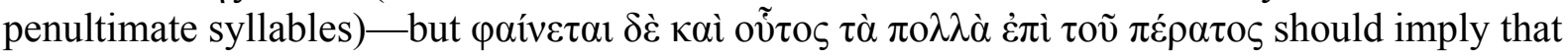
the circumflex is rather rare on penultimate syllables, which is hardly the case.

One response would be to bracket $\tau \grave{\alpha} \pi \mathrm{o} \lambda \lambda \dot{\alpha}$ as spurious, but given the other indications of a Latin source that we have seen, another possibility may be worth contemplating. Does the expression $\tau \grave{\alpha} \pi \mathrm{o} \lambda \lambda \dot{\alpha}$ reflect a comment in a Latin source to the effect that in Greek, unlike in Latin, the circumflex can often be found on the final syllable? Accents do not usually occur on final syllables in Latin, and Latin authors show themselves aware that Greek is different in this respect:

(24) Graeca nomina si isdem litteris proferuntur, Graecos accentus habebunt. nam et cum dicimus 'Thyias', 'Nais', acutum habebit posterior accentum, et cum 'Themisto', 'Callisto', ultima circumflectitur; quod utrumque Latinus sermo non patitur, nisi raro ... ([Sergius], in Donati Artem Maiorem, GL iv. 525. 8-11) Greek words, if they are produced with the same letters, will have Greek accents. For example, when we say 'Thyiăs', 'Naĭs', the last syllable will have an acute accent, and when (we say) 'Themistō', 'Callistō', the last syllable gets a circumflex - each of which is something that Latin speech does not allow, except rarely ... ${ }^{52}$

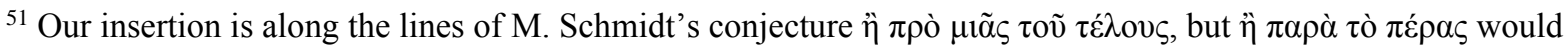

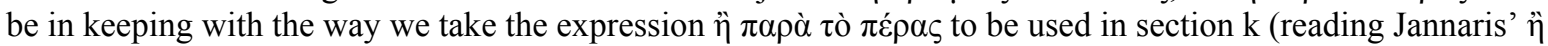
for the manuscripts' $\dot{\eta})$.

${ }^{52}$ For closely related parallel passages see Dositheus, Grammatica 3 Bonnet/GL vii. 379. 1/1-4/5; [Victorinus], De arte grammatica, GL vi. 193. 14-18; Audax, De Scauri et Palladii libris excerpta, GL vii. 330. 13-17. On the point that Themistō and Callistō are considered to have a circumflex on the final syllable when pronounced

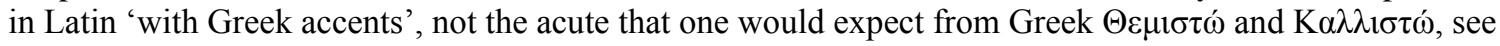
Probert (2019) 212-21, 240-42.
} 
In the Ars Laureshamensis from medieval Ireland, the point that accents (in this instance the acute) can fall on the final syllable in Greek is made more emphatically with the word frequenter: in Greek, unlike Latin, the accent 'often' falls on the final syllable. The author is commenting here on Donatus' point that among Latin speakers (apud Latinos) the acute accent can fall on the penultimate or antepenultimate syllable but never on the final syllable: ${ }^{53}$

(25) ideo addidit 'apud Latinos', quia apud Graecos frequenter acutus accentus ultimum locum tenet in dictione (Ars Laureshamensis 178. 25-26 Löfstedt)

He (i.e. Donatus) added 'among Latin speakers' because among the Greeks the acute accent often occupies the last place in the word.

From some such comment it would be a small step to our text's claim that the Greek circumflex 'mostly' appears on the final syllable. This explanation of $\tau \grave{\alpha} \pi \mathrm{o} \lambda \lambda \dot{\alpha}$ must remain tentative, but an explanation along these lines would fit well with the other evidence that the author of our text consulted a Latin source.

\subsection{Conclusion and further questions}

The case that the author of our text consulted a Latin source rests mainly on the points laid out in sections 3.3.1-3.3.5, for which the best parallels come from Latin rather than Greek grammatical texts. But a Latin source would also help to explain the use of unusual grammatical terminology, even where there is nothing obviously latinate about the terminology itself. If our author knew the standard Greek grammatical terms relating to prosody, they were not the Greek terms he reached for to render ideas he found in a Latin text, and the process of transferring Latin terms into Greek can be envisaged particularly clearly in relation to the use of '̇ $\pi \alpha \dot{\alpha} \delta \omega$ for 'sing along to' (section 3.4). We have also suggested, albeit tentatively, that a confusing point in the presentation of possible accent positions found towards the end of our text may be due to the slightly clumsy adaptation of material from a text that dealt mainly with the Latin accent and offered some side comments about Greek.

It remains to ask who consulted a Latin text in order to write about Greek prosodic signs, and when, and why. Both of the manuscripts containing our text date to the sixteenth century $\mathrm{AD}$, which therefore provides a secure terminus ante quem, but this does not narrow the possibilities down very much. As we saw in section 3.1, the language of our text is reminiscent of high-register Byzantine texts, and we have found no linguistic features suggestive of someone whose first language was Latin or a Romance language rather than Greek. Our text is likely then to have been produced by a Greek speaker, at a time when it was not too unusual for Greek speakers to know Latin. From this point of view the most likely periods are either fairly early or fairly late in the Byzantine period-or after the Fall of Constantinople in 1453, when the text could have been produced by a Greek speaker who had made his way to the west. ${ }^{54}$ This last possibility is attractive because it would help to explain why a Greek speaker resorted to a Latin text as his model for a Greek text on Greek prosodic signs.

It may be somewhat relevant that not only the copies of our text in manuscripts B and C, but their common (and presumably at least slightly earlier) source too appears to have been found in the west. In her recent study of Diassorinus, García Bueno concludes that he copied manuscript $C$ (folios $88^{r}-244^{r}$ ) in the Paris area around 1549-1550, while he was employed as

\footnotetext{
${ }^{53}$ Donatus, Ars maior 609. 7 Holtz = GL iv. 371. 4.

${ }^{54}$ On the Byzantine world's extensive (although never complete) loss of contact with western culture from the seventh century AD onwards, and on the gradual re-establishment of contact from the eleventh century onwards, see Ciccolella (2008) 229-36.
} 
a scriptor at the library at Fontainebleau. ${ }^{55}$ In other words, the common source of B and C appears to have been in the Paris area around this date, even if it need not have been produced in this area. Be this as it may, the style of our text suggests to us a late rather than early date for the composition of our text.

This conclusion does not necessarily entail that the unique information to be found in our text, on the subject of Aristophanes of Byzantium and his activities, can be dismissed out of hand as very late. Our author's Latin source must have been composed at least slightly earlier than our text itself, and could have been composed much earlier. As noted in section 3.3, our text contains some information that is otherwise found only in a late antique text known as Pseudo-Sergius' commentary on Donatus' Ars maior. Our author may have drawn other information too from the long tradition of commentaries on Donatus, and the ultimate source of the information remains obscure.

\section{Bibliography}

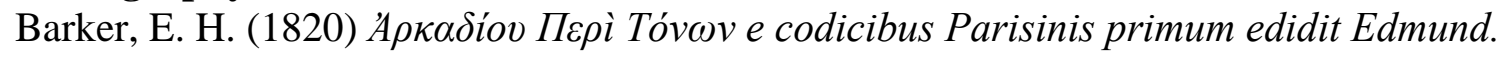
Henr. Barkerus (Leipzig)

Böhlig, G. (1956) Untersuchungen zum rhetorischen Sprachgebrauch der Byzantiner mit besonderer Berücksichtigung der Schriften des Michael Psellos (Berlin)

Braune, L. (1849) Review of Nauck (1848), Neue Jahrbücher für Philologie und Pädagogik $55,353-86$

Browning, R. (1978) 'The language of Byzantine literature', in S. Vryonis, Jr. (ed.), The 'Past' in Medieval and Modern Greek Culture (Malibu), 103-33

Callanan, C. K. (1987) Die Sprachbeschreibung bei Aristophanes von Byzanz (Göttingen)

Ciccolella, F. (2008) Donati Graeci: Learning Greek in the Renaissance (Leiden)

Cohn, L. (1888) 'Konstantin Palaeokappa und Jakob Diassorinus: La fraude de Palaeocappa concernant Castor de Rhodes, Zonaios et Héliodore de Brousse', in Philologische abhandlungen: Martin Hertz zum siebzigsten geburtstage von ehemaligen schülern dargebracht (Berlin), 123-43

De Paolis, P. (2000) 'Le Explanationes in Donatum (GL IV 486-565) e il loro più antico testimone manoscritto', in M. De Nonno, P. De Paolis and L. Holtz (eds), Manuscripts and Tradition of Grammatical Texts from Antiquity to the Renaissance, i (Cassino), 173-221

Galland, C. (1882) De Arcadii qui fertur libro de accentibus (Strasbourg)

García Bueno, C. (2017) El copista griego Jacobo Diasorino (s. XVI): estudio palaeográfico y codicológico de sus manuscritos (Ph.D. Diss. Universidad Complutense de Madrid) <https://eprints.ucm.es/45368>

Horrocks, G. (2010) Greek: A History of the Language and its Speakers, 2nd edn (Malden)

Jannaris, A. N. (1897) An Historical Greek Grammar (London)

Lameere, W. (1960) Aperçus de paléographie homérique (Paris)

Laum, B. (1928) Das Alexandrinische Akzentuationssystem (Paderborn)

Lentz, A. (1867) Herodiani technici reliquiae, i (Leipzig)

Lobeck, C. A. (1853) Pathologiae Graeci sermonis elementa (Königsberg)

Nagy, G. (2000) 'Reading Greek poetry aloud: evidence from the Bacchylides papyri' Quaderni Urbinati di Cultura Classica, new series 64, 7-28

Nauck, A. (1848) Aristophanis Byzantii grammatici Alexandrini fragmenta (Halle)

Pfeiffer, R. (1968) History of Classical Scholarship from the Beginnings to the End of the Hellenistic Age (Oxford)

\footnotetext{
55 García Bueno (2017) 184, 316. For Diassorinus' activities in the Paris area see also Cohn (1888) 140-43; Vogel and Gardthausen (1909) 152 n. 4; García Bueno (2017) 11, 125.
} 
Prauscello, L. (2006) Singing Alexandria: Music between Practice and Textual Transmission (Mnemosyne Supplement 274) (Leiden)

Probert, P. (2006) Ancient Greek Accentuation: Synchronic Patterns, Frequency Effects, and Prehistory (Oxford)

Probert, P. (2019) Latin grammarians on the Latin accent: the transformation of Greek grammatical thought (Oxford)

Roussou, S. (2018) Pseudo-Arcadius' Epitome of Herodian's De prosodia catholica (Oxford)

Schmidt, K. E. A. (1859) Beiträge zur Geschichte der Grammatik des Griechischen und Lateinischen (Halle)

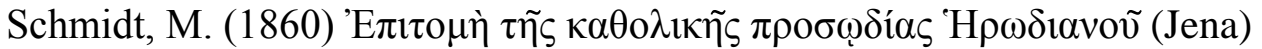

Schneider, R. (1887) Bodleiana (Leipzig)

Schwyzer, E. (1953) Griechische Grammatik, i (Munich)

Sophocles, E. A. (1887) Greek Lexicon of the Roman and Byzantine Periods (from B.C. 146 to A.D. 1100), Memorial edn (New York)

Villoison, J. B. C. d' Ansse de. (1783) Epistolae vinarienses (Zurich) <https://babel.hathitrust.org/cgi/pt?id=hvd.hxgfgx>

Vogel, M. and Gardthausen V. (1909) Die griechischen Schreiber des Mittelalters und der Renaissance (Leipzig)

Zetzel, J. E. G. (2018) Critics, Compilers, and Commentators: An Introduction to Roman Philology, 200 BCE-800 CE (New York)

\section{Ancient works}

[Alexandri] in Sophisticos elenchos commentarium = M. Wallies (ed.), Alexandri quod fertur in Aristotelis Sophisticos elenchos commentarium (Commentaria in Aristotelem Graeca, II.iii) (Berlin 1898)

Ap. Dysc., $A d v .=$ R. Schneider and G. Uhlig, Apollonii Dyscoli quae supersunt, $\mathrm{i}$ (Grammatici Graeci II.i) (Leipzig 1902) 117-210

Ap. Dysc., Constr. = J. Lallot, Apollonius Dyscole: De la construction (syntaxe) (Paris 1997)

Ap. Dysc., Pron. = P. Brandenburg, Apollonios Dyskolos: Über das Pronomen (Munich 2005)

[Arcadius] = S. Roussou, Pseudo-Arcadius' Epitome of Herodian's De Prosodia Catholica . (Oxford 2018)

Ars Laureshamensis = B. Löfstedt, Ars Laureshamensis: Expositio in Donatum maiorem (Corpus Christianorum, Continuatio Mediaevalis, 40A) (Turnhout 1977)

Audax, De Scauri et Palladii libris excerpta $=$ GL vii, 313-62

Cassiodorus, De orthographia $=G L$ vii, 127-210

Choeroboscus, Th. $=$ Georgii Choerobosci scholia in Theodosii Alexandrini canones, in A. Hilgard, Theodosii Alexandrini canones, Georgii Choerobosci scholia, Sophronii Patriarchae Alexandrini excerpta (Grammatici Graeci IV) (Leipzig 1889-1894) i, 103-ii, 371

Cledonius = C. Bernetti, Ars Cledonii Romani Senatoris Constantinopolitani Grammatici: Nuova edizione critica (Ph.D. Diss. Università degli Studi Roma Tre, 2011-2012) Available via the open access archive ArcAdiA at <http://hdl.handle.net/2307/4121>.

Diomedes, Ars $=$ GL i, 297-529

Dionysius of Halicarnassus, De compositione verborum = G. Aujac and M. Lebel (Budé) (Paris 1981)

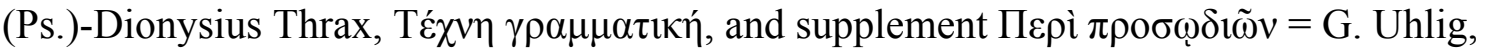
Dionysii Thracis Ars Grammatica (Grammatici Graeci I. i) (Leipzig 1883)

Donatus, Ars maior = L. Holtz, Donat et la tradition de l'enseignement grammatical: étude sur l'Ars Donati et sa diffusion (IVè̀-IXè siècle) et édition critique (Paris 1981) 603-74 
Donatus Ortigraphus = J. Chittenden, Donatus Ortigraphus, Ars grammatica (Corpus Christianorum, Continuatio Mediaevalis, 40D) (Turnhout 1982)

Dositheus, Grammatica = G. Bonnet (Budé) (Paris 2005)

Elias, In Porphyrii Isagogen et Aristotelis Categorias commentaria = A. Busse, Eliae in Porphyrii Isagogen et Aristotelis Categorias commentaria (Commentaria in Aristotelem Graeca, XVIII.i) (Berlin 1900)

Ep. Hom. alph. = Epimerismi Homerici qui ordine alphabetico traditi sunt, in A. R. Dyck, Epimerismi Homerici, ii (Berlin 1995) 1-822.

Etymologicum magnum = T. Gaisford, Etymologicum magnum (Oxford 1848)

Eustathius, In Iliadem = M. van der Valk, Eustathii archiepiscopi thessalonicensis commentarii ad Homeri Iliadem pertinentes (Leiden 1971-1987)

Excerpta Vaticana de positura, de chria, de poemate, de versu, de accentibus = GL vi. 27375

$G L=$ H. Keil. M. Hertz and T. Mommsen (eds), Grammatici Latini (Leipzig 1855-1880)

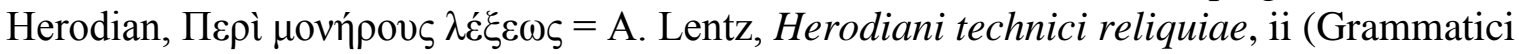
Graeci III.ii) (Leipzig 1870) 908-52

Homer, Iliad = M. L. West (Teubner) (Berlin/Munich 1998-2000)

Isidore of Seville, Etymologiae = W. M. Lindsay (OCT) (Oxford 1911)

John Philoponus, Praecepta tonica = G. A. Xenis, Iohannes Alexandrinus: Praecepta tonica (Berlin 2015)

Julian of Toledo, Ars grammatica = M. A. H. Maestre Yenes, Ars Iuliani Toletani episcopi (Toledo 1973)

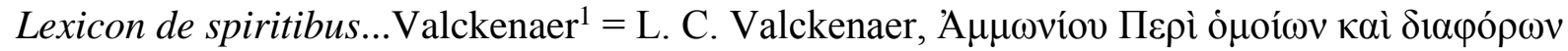
$\lambda \varepsilon \dot{\varepsilon} \xi \varepsilon \omega v$ : Ammonius, De adfinium vocabulorum differentia. Accedunt opuscula nondum edita (Leiden 1739) 205-42

Lexicon de spiritibus...Valckenaer ${ }^{2}=$ L. C. Valckenaer, Ammonius, De differentia adfinium vocabulorum. Accedunt opuscula nondum edita (Leipzig 1822) 188-215.

Martianus Capella, De nuptiis $=$ De nuptiis Philogiae et Mercurii, ed. J. Willis (Teubner) (Berlin 1983)

(Ps.?)-Michael Psellus, Philosophica minora i = J. M. Duffy, Michaelis Pselli philosophica minora, i: opuscula logica, physica, allegorica, alia (Teubner) (Leipzig 1992)

Michael Psellus, Oratoria minora = A. R. Littlewood (Teubner) (Leipzig 1985)

Murethach, In Donati Artem maiorem = L. Holtz, Murethach (Muridac), In Donati Artem maiorem (Corpus Christianorum, Continuatio Mediaevalis, 40) (Turnhout 1977)

Paraphrasis in Sophisticos elenchos = M. Hayduck, Anonymi in Aristotelis sophisticos elenchos paraphrasis (Commentaria in Aristotelem Graeca, XXIII.iv) (Berlin 1884)

Pompeius, Commentum Artis Donati $=$ GL v, 81-312

Sch. D. Thr. = A. Hilgard, Scholia in Dionysii Thracis Artem grammaticam (Grammatici Graeci I.iii) (Leipzig 1901)

Scholia ex Commentario I in Sophisticos elenchos extracta $=\mathrm{S}$. Ebbesen, Commentators and commentaries on Aristotle's Sophistici elenchi: a study of post-Aristotelian ancient and medieval writings on fallacies, ii (Corpus Latinum commentariorum in Aristotelem Graecorum, VII, 2.) (Leiden 1981) 241-72.

Sedulius Scottus, In Donati Artem maiorem = B. Löfstedt, Sedulius Scottus, In Donati Artem maiorem (Corpus Christianorum, Continuatio Mediaevalis, 40B) (Turnhout 1977)

[Sergius], in Donati Artem maiorem $=$ GL iv, 518 (line 30)-565 56

\footnotetext{
${ }^{56}$ Keil presents $G L$ iv, pp. 486-565 as a single work divided into two books ('Explanationum in Artem Donati Liber I' and 'Explanationum in Artem Donati Liber II'), with the second beginning at GL iv, p. 534, line 13. For the point that two distinct works are involved, with the second begining at GL iv, p. 518, line 30, see De Paolis (2000) 191-99; Zetzel (2018) 321-22.
} 
[Sergius], De littera, de syllaba, de pedibus, de accentibus, de distinctione $=$ GL iv, 473-85

Servius, Comm. in Donatum = GL iv, 403-48

Servius, De finalibus $=$ GL iv, 449-55

[Victorinus], De arte grammatica $=G L$ vi, 185-205 